\title{
How I Learned to Stop Worrying and Love the Pill: Adaptive Responses to Takeover Law
}

\author{
Marcel Kahan $\dagger$ \\ Edward B. Rock ††
}

This Article explores the relationship between takeovers, legal doctrines, and private ordering. The authors first argue that the sanctioning of the poison pill and the "just say no" defense by Delaware courts was far less consequential than feared by its critics and hoped for by its proponents. Rather, market participants adapted to these legal developments by embracing two adaptive devices-greater board independence and increased incentive compensation-which had the effect of transforming the pill, a potentially pernicious governance tool, into a device that is plausibly in shareholders' interest. Interestingly, however (and for critics of the pill, disconcertingly), market participants neither tried to change the law nor opt out of it. The authors place these developments in a broader perspective. They draw a distinction between bilateral devices-which enjoy support from both stockholders and managers-and unilateral devices, and argue that bilateral devices are more likely to be welfare-enhancing, are more stable, are privileged by Delaware law, and tend to further Delaware's status as leading domicile for public corporations. Greater board independence and increased incentive compensation are examples of such bilateral devices. The authors conclude by examining why Delaware courts embraced the poison pill (at the time, a largely unilateral device, albeit one with bilateral features) and how they should deal with the use of pills by companies with staggered boards.

\section{INTRODUCTION}

Twenty years ago, a wave of hostile takeovers burst on the scene and sparked a public debate over corporate control that continues to this day. Positions polarized quickly, with academics largely applauding the phenomenon and lawyers representing corporate boards largely decrying it. While some have modified their positions somewhat, the debate remains remarkably unchanged.'

\section{$\dagger$ Professor, New York University School of Law.}

t† Saul A. Fox Distinguished Professor of Business Law, University of Pennsylvania.

We thank Bill Allen, Jennifer Arlen, Lucian Bebchuk, Michael Bradley, Brian Cheffins, Rob Daines, Ehud Kamar, Reinier Kraakman, Paul Levy, Peter Siegelman, and David Skeel for helpful comments and Anand Damodaran for his excellent research assistance. We benefited from comments at The University of Chicago Law Review 2002 Symposium: Management and Control of the Modern Business Corporation, and from workshops at Fordham, Tel Aviv, Vanderbilt, and Cambridge. Marcel Kahan thanks the Filomen D'Agostino and Max E. Greenberg Research Fund for generous financial assistance. Edward Rock's research was supported by the University of Pennsylvania's Institute for Law and Economics.

1 See, for example, Lucian Arye Bebchuk, The Case Against Board Veto in Corporate Takeovers, 69 U Chi L Rev 975, 977-81 (arguing, as Bebchuk has since the 1980s, that boards should not be permitted to block noncoercive offers); Martin Lipton, Pills, Polls, and Professors 
Although it seemed at the time that the issues facing the Delaware courts - whether a poison pill was legal; whether managers could "just say no"-had decisive importance, somehow, in retrospect, they do not seem to have mattered quite so much. None of the parade of horribles predicted by partisans came to pass. Though takeover tactics have changed somewhat, the takeover game has continued along, its pace determined more by macroeconomic factors than by the details of legal doctrine, with new modes of gaining control developing as older methods have become more difficult. Most strikingly, despite judicial and legislative rejection of the academics' preference for relatively unrestricted hostile takeovers, and despite the granting of great discretion to managers to reject acquisition proposals that their shareholders might want to accept, merger and acquisition activity reached record levels during the 1990s.

What is one to make of this? In this Article, we seek to understand the relationship between legal doctrine and the world of takeovers, and to assess the significance of corporate law from a broader perspective. Our conclusion is that the role of courts is far less central than the partisans in the takeover debate assumed. Even the most important of the Delaware Supreme Court decisions seems, in retrospect, to be little more than a small piece of an overarching reequilibrating mechanism that adjusts to perturbations. This is an Article about the relationship between corporate law and private ordering.

In Part I, we briefly review the takeover scene of the 1980s and its subsequent evolution in the 1990s. The most prominent developments during this period were the increasing use of incentive compensation, the increasing independence of boards, and record levels of merger and acquisition ("M\&A") activity. Along with these developments, the line between hostile and friendly tender offers blurred. Also noteworthy are the changes that did not occur. Specifically, academics' favored rule-let the shareholders decide-did not win out in state legislatures, in courtrooms, or in private ordering schemes.

In Part II, we provide our interpretation of what happened. Market participants, faced with unsatisfactory law, can adapt in several ways. Put simply, they can try to change the law, opt out of the law, or work around the law. Each strategy has its own dynamics. We use this lens to analyze the market responses and nonresponses, and we conclude that the dominant mode of adaptation was through private mechanisms - what we will call "adaptive devices."

Redux, 69 U Chi L Rev 1037, 1064-66 (2002) (arguing, as Lipton has since the 1970s, that the decision whether to accept or reject an acquisition offer was primarily for the board of directors); Ronald J. Gilson, Unocal Fifteen Years Later (And What We Can Do About It), 26 Del J Corp L 491, 507-09 (2001) (arguing, as Gilson has since the 1980s, that the shareholders should decide whether to accept or reject a bid for control). 
In Part III, we consider the implications of this analysis for understanding Delaware corporate law in general and takeover law in particular. The takeover experience emphasizes how the possibility of adaptive responses makes it very difficult to predict the effects of legal developments. At the same time, the Delaware takeover jurisprudence illustrates a deep preference in Delaware corporate law for bilateral rather than unilateral responses. This tilt towards consensus has implications both for the stability of particular responses and for Delaware's position as the leading corporate domicile-effects that we explore in some detail. Finally, we return to poison pills and examine how the pill contributed to a new equilibrium that transformed the pill into a device that plausibly is in shareholders' interest and, in any event, one that shareholders can easily live with. We conclude with a discussion of the interaction of poison pills and staggered boards, and the danger that equilibria can become stale and entrenched.

\section{TAKEOVERS IN THE 1980S AND THEIR AFTERMATH}

\section{A. The $1980 \mathrm{~s}$}

During the 1980s, a huge takeover wave hit corporate America. As indicated in Table 1, M\&A activity increased from $\$ 44$ billion in 1980 to $\$ 247$ billion in $1988 .^{2}$ A substantial portion of the deals during this period were hostile takeovers or defensive transactions undertaken in response to hostile takeovers. ${ }^{3}$

2 See Mergerstat, M\&A Activity-U.S. and U.S. Cross-Border Transactions (2001), available online at <http://www.mergerstat1.com/free_reports/free_reports_m_and_a_activity.asp> (visited Mar 31, 2002).

3 See, for example, City Capital Association, LLP v Interco, Inc, 551 A2d 787, 801-03 (Del Ch 1988) (discussing defensive recapitalization in response to a hostile bid). 
TABLE 1

M\&A ACTIVTTY: 1980-88

\begin{tabular}{|l|l|l|}
\hline Year & Deals & Value (\$ bil) \\
\hline 1980 & 1,889 & $\$ 44.3$ \\
1981 & 2,395 & $\$ 82.6$ \\
1982 & 2,533 & $\$ 53.8$ \\
1983 & 2,543 & $\$ 73.1$ \\
1984 & 2,543 & $\$ 122.2$ \\
1985 & 3,001 & $\$ 179.8$ \\
1986 & 3,336 & $\$ 173.1$ \\
1987 & 2,032 & $\$ 163.7$ \\
1988 & 2,258 & $\$ 246.9$ \\
\hline
\end{tabular}

Source: Mergerstat.

Whether the takeovers of the 1980s enhanced overall economic efficiency is disputed. ${ }^{4}$ What is clear, however, is that these takeovers spawned substantial innovation in corporate legal doctrine $e^{5}$ and reinvigorated corporate legal scholarship. ${ }^{6}$ Most of the doctrinal and scholarly focus was on the validity of so-called defensive tactics employed by target managers to fend off a hostile tender offer or, more generally, on the division of power between target managers and target shareholders in deciding whether the company should be sold. ' In

4 See Roberta Romano, A Guide to Takeovers: Theory, Evidence, and Regulation, 9 Yale J Reg 119,122-54 (1992) (providing a survey of the academic literature).

5 See, for example, Jesse H. Choper, John C. Coffee, Jr., and Ronald J. Gilson, Cases and Materials on Corporations 887-1079 (Aspen 4th ed 1995) (devoting almost $20 \%$ of the casebook to chapters on corporate acquisitions, takeovers, and control transactions).

6 See David W. Leebron, Games Corporations Play: $A$ Theory of Tender Offers, 61 NYU L Rev 153, 154 (1986) ("The nearly obligatory observation commencing any writing on the subject of tender offers is that no machination of the corporate or financial world has ever attracted greater attention from lawyers, legal scholars, financial economists, or the lay press."); Bayless Manning, The Shareholder's Appraisal Remedy: An Essay for Frank Coker, 72 Yale L J 223, 245 n 37 (1962) (arguing, prior to the advent of takeovers, that "corporation law, as a field of intellectual effort, is dead in the United States").

7 See, for example, Marcel Kahan and Michael Klausner, Lockups and the Market for Corporate Control, 48 Stan L Rev 1539, 1552-58, 1564-70 (1996) (arguing for strict judicial scrutiny of second-bidder lockups); Ronald J. Gilson and Reinier Kraakman, What Triggers Revlon?, 25 Wake Forest L Rev 37, 39-46 (1990) (examining the implications to shareholders and management of Revlon analysis in the context of a hostile bid); Ronald J. Gilson and Reinier Kraakman, Delaware's Intermediate Standard for Defensive Tactics: Is There Substance to Proportionality Review?, 44 Bus Law 247, 248 (1989) (analyzing Delaware's "intermediate standard of re- 
the early 1980 s, target managers resorted to a variety of exotic sounding defensive tactics, ranging from "shark repellants" to "greenmail," and from "white knights"10 to the "Pac-Man" defense. "Quickly, however, a new weapon in the defensive arsenal-the "poison pill"rendered most other defenses moot. Compared to other defenses, the poison pill had several important advantages for target managers. A pill could be adopted by any company at any time without shareholder approval ${ }^{12}$ adoption of a pill did not entail significant transaction costs and did not, apart from its effect on takeovers, affect the conduct of the company's business; and, most importantly, a pill made a company takeover-proof unless redeemed by the target board. ${ }^{13}$

view"); Jonathan R. Macey and Fred S. McChesney, A Theoretical Analysis of Corporate Greenmail, 95 Yale L J 13, 60 (1985) (arguing "in favor of applying the traditional business judgment rule to challenges of greenmail payments"); Lucian A. Bebchuk, Toward Undistorted Choice and Equal Treatment in Corporate Takeovers, 98 Harv L Rev 1693, 1747-63 (1985) (proposing a scheme to address the problem of coercive offers); Louis Lowenstein, Pruning Deadwood in Hostile Takeovers: A Proposal for Legislation, 83 Colum L Rev 249, 254-55 (1983) (proposing legislation that would permit shareholders to decide whether to approve management's response to a hostile bid); Lucian A. Bebchuk, The Case for Facilitating Competing Tender Offers, 95 Harv L Rev 1028, 1030 (1982) (supporting a rule of auctioneering); Lucian Arye Bebchuk, The Case for Facilitating Competing Tender Offers: A Reply and Extension, 35 Stan L Rev 23, 49 (1982) (favoring a rule that facilitates competing bids); Ronald J. Gilson, The Case against Shark Repellent Amendments: Structural Limitations on the Enabling Concept, 34 Stan L Rev 774, 836 (1982) (arguing that state corporation statutes should be interpreted not to authorize "shark repellant" amendments-amendments to a target's articles of incorporation that make acquisition less desirable and more difficult); Frank H. Easterbrook and Daniel R. Fischel, Auctions and Sunk Costs in Tender Offers, 35 Stan L Rev 1, 21 (1982) (bolstering their argument "that a no-auction rule maximizes the wealth of investors and society" in response to the criticism of Bebchuk and Gilson); Frank H. Easterbrook and Daniel R. Fischel, Corporate Control Transactions, 91 Yale L $\mathrm{J}$ 698, 715 (1982) (arguing that "[i]nvestors' welfare is maximized by a legal rule that permits unequal division of gains" from such transactions); Frank H. Easterbrook and Daniel R. Fischel, The Proper Role of a Target's Management in Responding to a Tender Offer, 94 Harv L Rev 1161, 1201 (1981) (arguing that shareholders would want management to be passive in the face of a tender offer); Ronald J. Gilson, A Structural Approach to Corporations: The Case against Defensive Tactics in Tender Offers, 33 Stan L Rev 819, 865 (1981) (arguing that the "corporate structure assigns to shareholders the decisionmaking role in tender offers" and that management's proper role in such situations is limited to "aid[ing] the shareholder in making the decision"); Martin Lipton, Takeover Bids in the Target's Boardroom, 35 Bus Law 101, 105 (1979) (stating that "proscribing the ability of companies to defend against takeovers would adversely affect long-term planning"). ments).

8 See Gilson, 34 Stan L Rev at 777 (cited in note 7) (defining shark repellant amend-

9 See Macey and McChesney, 95 Yale L J at 13 (cited in note 7) (defining greenmail as negotiated stock repurchases).

10 See Revlon, Inc v MacAndrews \& Forbes Holdings, Inc, 506 A2d 173, 183 (Del 1986) (using the phrase to describe a bidder sought by a target to counter a disfavored bid).

11 See Ronald Gilson and Bernard Black, The Law and Finance of Corporate Acquisitions 771-72 (Foundation 2d ed 1995) (quoting a merger specialist who stated that the defense occurred when "my client eats yours before yours eats mine").

12 See id at 747 (noting that "[a] central characteristic of a poison pill plan is that shareholder approval is not required for adoption").

13 See Martin Lipton, Wachtell, Lipton, Rosen \& Katz, Memorandum to Clients (Jan 15, 
Because any company could quickly create a poison pill and because a pill was so effective, the doctrinal and academic interest soon turned to the circumstances in which target managers could refuse to redeem the pill-and thereby prevent target shareholders from accepting a hostile tender offer. ${ }^{14}$ One question in particular was considered to be highly important by practitioners, academics, and courts alike: Could a target board (as recommended to the nation's youth by the then-First Lady) "just say no" and refuse to redeem a pill indefinitely, based on its assertion that it believed in good faith that the hostile bid was too low? It took the Delaware courts until the end of the 1980 s to address this issue authoritatively. ${ }^{15}$ During this period, prominent legal scholars painted in dark colors the world in which a "just say no" defense was valid. ${ }^{16}$ For them, the power of shareholders to accept a takeover bid without board interference was a crucial ele-

1993) ("[The poison pill] is an absolute bar to a raider acquiring control of the company ... without the approval of the company's board of directors."), quoted in Joseph A. Grundfest, Just Vote No: A Minimalist Strategy for Dealing with Barbarians inside the Gates, 45 Stan L Rev 857, $859 \mathrm{n}$ 4 (1993).

14 See Gilson and Kraakman, 44 Bus Law at 256-60 (cited in note 7) (examining what constitutes a "threat" that warrants a defensive response); Interco, 551 A2d at 798 (finding "that in the setting of a noncoercive offer, absent unusual facts, there may come a time when a board's fiduciary duty will require it to redeem the [pill] and to permit the shareholders to choose").

15 See text accompanying notes $21-31$.

16 See, for example, Jonathan R. Macey, The Legality and Utility of the Shareholder Rights Bylaw, 26 Hofstra L Rev 835, 837 (1998):

Unfortunately, poison pills have become deal breakers. Courts have become far too reluctant to second-guess directors who refuse to eliminate their firms' pills. These courts are shirking their responsibility to safeguard shareholder value by failing to enforce fiduciary duties and by failing to police director and management conflicts of interest. Target firms can now keep their poison pills in place and "just say no" to would-be acquirers, regardless of the market premiums these acquirers are willing to pay to shareholders.

See also Grundfest, 45 Stan L Rev at 858, 862, 864 (cited in note 13):

The takeover wars are over. Management won. Although hostile tender offers remain technically possible, the legal and financial barriers in their path are far higher today than they were a few short years ago. As a result, it will be difficult for hostile bidders to prevail in takeover battles, even if shareholders support the insurgents' efforts... This remarkable transformation in the market for corporate control resulted from the emergence of the "poison pill" as an effective antitakeover device.... With the demise of the hostile takeover, shareholders can no longer expect much help from the capital markets in disciplining or removing inefficient managers. ... As a result, corporate America is now governed by directors who are largely impervious to capital market or electoral challenges.

See also Ronald J. Gilson, Seeking Competitive Bids versus Pure Passivity in Tender Offer Defense, 35 Stan L Rev 51, 52 (1982):

[T] here is no coherent justification for allowing target management to engage in defensive tactics that may deprive shareholders of the opportunity to tender their shares. Corporate managers must face up to the fact that such conduct benefits only themselves. State courts must recognize that the legal rules that facilitate this conduct, under the guise of deference to business judgment, do no more than sanction corporate treason. 
ment of a well-functioning system of corporate governance. ${ }^{17}$ Epitomizing this view, Professors Ronald Gilson and Reinier Kraakman described the question of whether target managers could preclude shareholders from accepting a noncoercive bid because they believed that the price was inadequate as the "single most important issue" in takeover law. ${ }^{18}$ On the flip side of the coin, when a ruling by the Delaware Chancery Court appeared to reject the "just say no" defense," Martin Lipton of Wachtell, Lipton, Rosen \& Katz, a leading M\&A law firm, sent a notorious memorandum to his clients characterizing the ruling as a "dagger aimed at the hearts of all Delaware corporations" and advising them that they might have to consider reincorporating in a different state. ${ }^{20} \mathrm{~A}$ lot, it appeared, turned on the validity of the defense.

Beleaguered target managers thus must have breathed a collective sigh of relief when the Delaware Supreme Court issued its opinion in Paramount Communications, Inc v Time, Inc ("Time-Warner")." In Time-Warner, the court permitted the board of Time, faced with a hostile, conditional tender offer by Paramount, to proceed with its own tender offer for Warner Brothers and to retain its poison pill. ${ }^{22}$ The decision of Time's board was based on the opinion, shared by the board's outside directors and supported by a fairness opinion by Time's investment bank, that Paramount's conditional offer of $\$ 200$ per share-a $58 \%$ premium over Time's pre-offer share price-was inadequate. ${ }^{23}$ Without closer scrutiny of the reasonableness of the decision and the process in which it was reached, the Delaware Supreme Court held that "[d]irectors are not obliged to abandon a deliberately conceived corporate plan for a short-term shareholder profit unless there is clearly no basis to sustain the corporate strategy," ${ }^{24}$ and criticized the earlier Chancery Court decision that stimulated Lipton's memorandum as a "narrow and rigid" interpretation of Delaware law. $^{25}$

17 See, for example, Frank H. Easterbrook and Daniel R. Fischel, The Economic Structure of Corporate Law 171-74 (Harvard 1991) (discussing the importance of tender offers and the prohibition of target resistance for controlling agency costs); Gilson, 33 Stan L Rev at 841-48 (cited in note 7) (describing the tender offer as having a critical role in the corporate structure and explaining why defensive tactics undermine that role).

18 Gilson and Kraakman, 44 Bus Law at 258 (cited in note 7).

19 Interco, $551 \mathrm{~A} 2 \mathrm{~d}$ at 798.

20 See Jeffrey N. Gordon, Corporations, Markets, and Courts, 91 Colum L Rev 1931, 1959 n 95 (1991) (quoting from the memorandum).

$21 \quad 571$ A2d 1140 (Del 1989).

22 See id at 1141.

23 See id at 1149.

24 Id at 1154.

25 Id at 1153. 
Most commentators have read Time-Warner to fortify the power of a board to "just say no." ${ }^{26}$ To be sure, even after Time-Warner, some limits on the target board's ability to "just say no" exist. Delaware courts may be more skeptical of an assertion that a price offered in a hostile bid is inadequate if this assertion does not enjoy the support of the board's outside directors or if the board failed to obtain a fairness opinion. ${ }^{27}$ Furthermore, once a change in control is inevitable, a target can no longer "just say no" to a competing bidder. ${ }^{28}$ Finally, despite its sweeping language, Time-Warner involved peculiar facts that could be used by future court opinions to limit its holding. ${ }^{29}$ Despite these caveats, however, outside Revlon, ${ }^{30}$ no Delaware case after Time-Warner has suggested that a board may have to redeem a poison pill if the independent directors, with the advice of an investment bank, conclude that a hostile bid is too low.

\section{B. The Aftermath}

Merger and acquisition activity declined sharply around the time of the Time-Warner decision and in its immediate aftermath, with the decline in hostile acquisitions being particularly pronounced. As indicated in Table 2, the value of M\&A deals fell from its 1988 peak of $\$ 247$ billion, to $\$ 221$ billion in 1989 , to $\$ 108$ billion in 1990 , and then to

26 See, for example, Marcel Kahan, Paramount or Paradox: The Delaware Supreme Court's Takeover Jurisprudence, $19 \mathrm{~J}$ Corp L 583, 604 (1994) (arguing that Delaware law validates the use of the poison pill to "just say no"); Grundfest, 45 Stan L Rev at 859 n 4 (cited in note 13) (concluding that most commentators believe that Time-Warner greatly strengthened the board's ability to reject a noncoercive bid); Gordon, 91 Colum L Rev at 1932 (cited in note 20) (noting that Time-Warner "came close to explicitly sanctioning a 'just say no' defense"); Theodore N. Mirvis, Time/Warner: The Delaware Supreme Court Speaks, NY Law J 5, 6 (Mar 29, 1990) ("[T]he opinion is an undeniable endorsement of 'Just Say No' where the decision not to redeem the pill is made in good faith and on an informed basis."); James C. Freund and Rodman Ward, Jr., What's 'In,' 'Out' in Takeovers in Wake of Paramount v. Time, Natl L J 22, 25 (Mar 26, 1990) ("The 'just say no' defense is definitely looking better and better.").

27 See Kahan, $19 \mathrm{~J}$ Corp L at 605 (cited in note 26) (noting that a decision to reject an offer will be analyzed according to certain factors, including whether the decision was supported by the independent directors and whether the board had adequate information).

28 See Paramount Communications, Inc v QVC Network, Inc, 637 A2d 34, 48 (Del 1993) (holding that when a corporation undertakes a transaction that will cause a change in corporate control, the directors' obligation is to seek the best value available to the shareholders).

29 In $Q V C$, the Delaware Supreme Court retreated from portions of the Time-Warner opinion, explaining when a target board is subject to Revlon duties. Id at 47 (stating that the defendants had "misread the holding of Time-Warner" and going on to emphasize that a breakup did not need to be inevitable before Revlon duties were triggered). Until now, however, no Delaware case has limited the portions of Time-Warner that deal with the permissibility of the "just say no" defense.

30 Revlon, Inc v MacAndrews \& Forbes Holdings, Inc, 506 A2d 173 (Del 1986).

31 See, for example, Unitrin, Inc v American General Corp, 651 A2d 1361, 1375-76 (Del 1995) (upholding the use of defensive measures by a target board in such circumstances). 
$\$ 71$ billion in $1991 .^{32}$ The level of hostile acquisition in that period declined by over $90 \% .{ }^{33}$ This downturn was attributed to several causes: a slowdown in the economy, the collapse of the junk bond market, and last but not least, the enhanced level of takeover protection offered by corporate law. ${ }^{34}$ The decline thus seemed to validate the views of scholars and practitioners about the significance of "just say no."

TABLE 2

M\&A ACTIVITY: 1988-1991

\begin{tabular}{|c|c|c|}
\hline Year & Deals & Value (\$ bil) \\
\hline 1988 & 2,258 & $\$ 246.9$ \\
1989 & 2,366 & $\$ 221.1$ \\
1990 & 2,074 & $\$ 108.2$ \\
1991 & 1,877 & $\$ 71.2$ \\
\hline
\end{tabular}

Source: Mergerstat.

The dip in takeovers, however, turned out to be short-lived. As indicated in Table 3, M\&A activity reached unprecedented levels as the economy rebounded. ${ }^{35}$ By 1995 , the level of M\&A activity exceeded the previous 1988 record. In the millennial year 2000, it reached a volume of $\$ 1.285$ trillion on over ten thousand deals, thus topping activity in 1988 by over $400 \%$ in dollar terms and by over $300 \%$ in the number of deals. ${ }^{36}$

32 See Mergerstat, $M \& A$ Activity (cited in note 2).

33 Hostile acquisitions fell from almost $\$ 127$ billion in 1988 , to about $\$ 45.5$ billion in 1989 , to a little more than $\$ 11$ billion in 1990. Securities Data Co, The 1991 Domestic Merger Yearbook 9 (1991).

34 See, for example, Grundfest, 45 Stan L Rev at 858 (cited in note 13) (claiming that the end of the "takeover wars" resulted "from the emergence of the "poison pill' ... state antitakeover statutes, and the development of financial market conditions inimical to hostile control contests"). Gordon, 91 Colum L Rev at 1931-32 (cited in note 20) (listing these among causes for the decline in acquisition activity).

35 See, for example, Paul M. Sherer, Review of Markets: The Lesson from Chrysler, Citicorp and Mobil: No Companies Nowadays Are Too Big to Merge, Wall St J R8 (Jan 4,1999) (noting that in every year since 1995, the volume and value of U.S. deals exceeded previous records).

36 See Mergerstat, $M \& A$ Activity (cited in note 2). 
TABLE 3

M\&A ACTIVITY: $1990-2000$

\begin{tabular}{|c|r|r|}
\hline Year & Dealls & Value (\$ bil) \\
\hline 1990 & 2,074 & $\$ 108.2$ \\
1991 & 1,877 & $\$ 71.2$ \\
1992 & 2,574 & $\$ 96.7$ \\
1993 & 2,663 & $\$ 176.4$ \\
1994 & 2,997 & $\$ 226.7$ \\
1995 & 3,510 & $\$ 356.0$ \\
1996 & 5,848 & $\$ 495.0$ \\
1997 & 7,800 & $\$ 657.1$ \\
1998 & 7,809 & $\$ 1,192.9$ \\
1999 & 9,278 & $\$ 1,425.9$ \\
2000 & 10,883 & $\$ 1,284.8$ \\
\hline
\end{tabular}

Source: Mergerstat.

The revival of takeovers was accompanied by several other changes, both in the structure of takeovers and corporate governance and in academic thinking. Hostile bids continued to be made. Responding to the "just say no" defense, such bids either were accompanied by the threat of a proxy contest to replace the incumbent board ${ }^{37}$ or were instituted after the target agreed to be acquired by another company. ${ }^{38}$ Contrary to the 1980 s, however, the vast majority of takeover bids in the second part of the 1990s were nominally friendly. ${ }^{39}$

But at the same time as the composition of bids shifted, the line between "friendly bids" and "hostile bids," both in the eyes of practitioners and academics, became blurred. In the 1980s, renowned hostile takeover artists such as T. Boone Pickens, Carl Icahn, and Ronald Perelman were viewed as making "financial" and "bust-up" hostile bids (so-called because of the lack of obvious synergies between the bidder and the target and the bidder's plan to sell off non-core assets

37 The new board could then redeem the poison pill and let the bid go forward.

38 Having agreed to a sale or a change of control, the target company could not use a poison pill to block a hostile bid at a higher price. See $Q V C, 637$ A2d at 48; note 28.

39 Joseph H. Flom, Mergers \& Acquisitions: The Decade in Review, 54 U Miami L Rev 753, $761-62$ (2000) (noting that the number of hostile transactions was small in comparison with the total number of transactions). 
to repay debt incurred in the acquisition). ${ }^{40}$ One of the best known takeover law firms, Wachtell, Lipton, categorically refused to represent hostile bidders." Academics, in turn, sharply distinguished between hostile bids, designed primarily to discipline target managers and replace them with a different management team, and friendly bids, designed to generate synergies. ${ }^{42}$ But by the late 1990 s, both friendly and hostile bids were regularly made by Fortune 500 companies in related industries; ${ }^{43}$ Wachtell, Lipton had represented hostile bidders in some of the most widely-known takeover battles; ${ }^{44}$ and academics had started to view friendly and hostile bids as reflecting tenuous distinctions in negotiating strategies and in the timing of the disclosure of takeover talks. ${ }^{45}$

Accompanying the shift in types of takeovers and the blurring distinction between them are two other gradual changes in the governance structure for public corporations. First, both anecdotal evidence and empirical studies suggest that outside directors exert more power in the boardroom than they did previously. Several studies find that the percentage of outside directors on corporate boards has increased. ${ }^{45}$ While in the 1960 s boards had a majority of inside directors, ${ }^{47}$

40 See Moran v Household International, Inc, 490 A2d 1059, 1064 (Del Ch 1985) (noting the argument that the pill is designed to deter hostile, bust-up bids).

41 See Edward Felsenthal, Raiders' Enemy in '80s Takes Surprising Path, Wall St J B8 (Nov 19,1993 ) (noting that the decision by Wachtell, Lipton, Rosen \& Katz to represent QVC in its hostile takeover bid for Paramount was a reversal of its former policy that hostile takeovers were destroying companies and undermining the U.S. economy).

42 See, for example, Easterbrook and Fischel, 94 Harv L Rev at 1169-73 (cited in note 7) (arguing that hostile bids are motivated by a desire to replace target management); Gilson, 33 Stan L Rev at 841-45 (cited in note 7) (viewing tender offers as prime mechanism to replace inefficient or self-dealing management); Randall Morck, Andrei Shleifer, and Robert W. Vishny, Characteristics of Targets of Hostile and Friendly Takeovers, in Alan J. Auerbach, ed, Corporate Takeovers: Causes and Consequences 101, 104-26 (Chicago 1988) (providing empirical evidence that hostile takeovers are disciplinary, while friendly takeovers are synergistic).

43 See, for example, GE Seeks Kemper Shareholder List, Chi Sun-Times 45 (Mar 22, 1994) (noting GE's hostile bid for Kemper); Northrop to Launch Hostile Offer for Grumman, UPI (Mar 10, 1994); NCR Corp Responds to AT\&T Offer, Bus Wire (Dec 5, 1990). See also Flom, 54 U Miami L Rev at 761-62 (cited in note 39) (noting that a number of major firms, such as GE, AT\&T, and IBM, engaged in hostile takeover activity in the 1990s).

44 See Felsenthal, Raiders' Enemy in '80s Takes Surprising Path, Wall St J at B8 (cited in note 41) (noting that the firm has represented QVC and AT\&T in hostile takeover bids).

45 See, for example, G. William Schwert, Hostility in Takeovers: In the Eyes of the Beholder?, 55 J Fin 2599, 2601-38 (2000) (finding empirical evidence that hostile and friendly deals are not distinguishable in economic terms, except that hostile transactions involve publicity as part of the bargaining process); Robert Daines and Michael Klausner, Do IPO Charters Maximize Firm Values?: Antitakeover Protection in IPOs, $17 \mathrm{~J} \mathrm{~L}$, Econ, \& Org 83, 98 (2001) (noting that friendly and hostile transactions are "substitutes").

46 See, for example, Sanjai Bhagat and Bernard Black, The Uncertain Relationship between Board Composition and Firm Performance, 54 Bus Law 921, 922, 940-50 (1999) (reporting an increased percentage of outside directors); James Kristie, Board Trends 1970s to the 1990s: "The More Things Change ...," presentation to the Institutional Shareholder Services Annual Client Conference (Feb 26, 1999), available online at <http:/www.directorsandboards.com/ 
a survey of board composition in 1999 reports that the average board consists of nine outside and only two inside directors. ${ }^{48}$ The increase in the percentage of outside directors seems particularly pronounced in companies incorporated in states that have adopted severe antitakeover laws. ${ }^{49}$ Moreover, outside directors are not mere lackeys of management. Several studies based on pre-1990 data document, among other things, ${ }^{50}$ that outside directors make it more likely that poorly performing CEOs are fired ${ }^{\text {st }}$ that they enhance shareholder wealth during tender offers; ${ }^{32}$ that they reduce the extent to which CEOs are rewarded for luck; ${ }^{53}$ that their appointment is associated with an increase in the stock price; $;^{54}$ and that majority-independent boards are associated with higher premia in management buyouts. ${ }^{55}$ More recent data suggest that outside directors have increasing influence over the

brdtrnds.html $>$ (visited Mar 28, 2002) (reporting the increasing percentage of outside directors).

47 See Bhagat and Black, 54 Bus Law at 921 (cited in note 46) ("In the 1960s, most [American public companies] had a majority of inside directors.").

48 Korn/Ferry International, 27th Annual Board of Directors Study (2000). See also Mark R. Huson, Robert Parrino, and Laura T. Starks, Internal Monitoring Mechanisms and CEO Turnover: A Long-Term Perspective, $56 \mathrm{~J}$ Fin 2265, 2276 (2001) (reporting that the mean number of non-officer directors has increased from $65.9 \%$ in $1971-1976$ to $76.5 \%$ in 1989-1994).

49 See Chun-Keung Hoi, Jeffrey Lessard, and Ashok Robin, The Effect of State AntiTakeover Laws on Board Composition, 18 Am Bus Rev 9, 13-17 (2000) (examining the board composition of Ohio and Pennsylvania companies and finding that the proportion of outside directors in companies incorporated in these states increased at a higher rate than in companies incorporated in other states).

so For an overview of these studies, see generally Bhagat and Black, 54 Bus Law at 921 (cited in note 46).

51 See Michael S. Weisbach, Outside Directors and CEO Turnover, $20 \mathrm{~J}$ Fin Econ 431, 458 (1988) (concluding that "performance measures are more highly correlated with CEO turnover for firms in which outsiders dominate the boards"); Rick Geddes and Hrishikesh D. Vinod, CEO Tenure, Board Composition and Regulation at 25, working paper (1998), available online at <http://papers.ssrn.com/id=139266> (visited Mar 28, 2002) (finding "shorter tenures for CEOs on outsider dominated boards"). See also Kenneth A. Borokhovich, Robert Parrino, and Teresa Trapani, Outside Directors and CEO Selection, 31 J Fin \& Quant Anal 337, 346-53 (1996) (finding, based on 1970 to 1988 data, that the percentage of outside directors is positively related to outside CEO succession and that shareholders benefit from outside succession).

52 See James F. Cotter, Anil Shivdasani, and Marc Zenner, Do Independent Directors Enhance Target Shareholder Wealth During Tender Offers?, 43 J Fin Econ 195, 216 (1997) (using 1989 to 1992 data and concluding that outside directors are more likely to resist bids to extract higher premia than to entrench management).

53 See Marianne Bertrand and Sendhil Mullainathan, Do CEOs Set Their Own Pay? The Ones Without Principals Do at 27, MIT Working Paper No 00-26 (Jan 2000), available online at $<$ http://papers.nber.org/papers/w7604.pdf> (visited Apr 19, 2002) (finding that insider presence on a board increased pay for luck).

54 See Stuart Rosenstein and Jeffrey G. Wyatt, Outside Directors, Board Independence, and Shareholder Wealth, $26 \mathrm{~J}$ Fin Econ 175, 190 (1990) (concluding that "the addition of an outside director increases firm value").

55 See Chun I. Lee, et al, Board Composition and Shareholder Wealth: The Case of Management Buyouts, Fin Mgmt 58, 71 (Spring 1992) (concluding that "boards dominated by independent members are associated with larger abnormal returns" in management buyouts). 
composition of board committees; ${ }^{56}$ that they dominate the composition of board committees, including the nominating committee, ${ }^{57}$ and that CEO tenure has declined and CEO terminations have increased $^{\text {sis }}-\mathrm{a}$ trend attributed, at least in part, to more independent boards. ${ }^{59}$ Consistent with these data, corporate governance experts have concluded that boards have become more effective monitors during the $1990 \mathrm{~s}^{60}$ As a result of the increasing number and increasing

56 See Korn/Ferry International, press release, Korn/Ferry's 28th Annual Board of Directors Study Finds CEO, Board Evaluations on Upswing, Outsiders Deciding Committee Membership, Compensation Static (2001), available online at <http://www.kornferry.com/pr/ pr_01_0904_board_evaluations.asp> (visited Mar 28, 2002) (reporting that the percentage of respondents saying that the CEO chose committee chairs and members declined from $57 \%$ in 1996 to $37 \%$ in 2001); Kristie, Board Trends 1970s to the 1990s (cited in note 46) (reporting that directors believe that it will become accepted practice for boards, rather than CEOs, to appoint committee members and chairs).

57 See Korn/Ferry International, 27th Annual Board of Directors Study (2000) (cited in note 48) (finding that, with respect to eleven types of committees surveyed, seven typesincluding the nominating committee-are on average composed only of outside directors, three types have insider directors who are a minority of the committee members, and one type (the executive committee) has the same number of outside and insider directors). See also Anil Shivdasani and David Yermack, CEO Involvement in the Selection of New Board Members: An Empirical Analysis, 54 J Fin 1829, 1851 (1999) (reporting that the influence of CEOs over board members has declined); Kristie, Board Trends 1970s to the 1990s (cited in note 46) (reporting that the percentage of companies with nominating committees increased from $2 \%$ in 1973 , to $60 \%$ in 1988 , to $75 \%$ in 1999 ).

58 See Tom Neff and Dayton Ogden, Anatomy of a CEO, Chief Executive 30, 31 (Feb 2001) (reporting that median tenure of CEOs in office declined from seven years in 1980 to five years in 2000); Huson, Parrino, and Starks, $56 \mathrm{~J}$ Fin at 2278-79 (cited in note 48) (finding an increase in forced CEO turnover in the 1971 to 1994 period); Denis B.K. Lyons, CEO Casualties: $A$ Battlefront Report, Directors \& Boards 43 (Summer 1999) (reporting that the percentage of Fortune 100 companies with CEOs with tenure of five years or less increased from $46 \%$ in 1980 to $58 \%$ in 1998); CEO Tumover Up, SF Bus Times (July 6, 2001), available online at $<$ http://sanfrancisco.bizjournals.com/sanfrancisco/stories/2001/07/02/daily32.html> (visited Mar 29,2002 ) (reporting increase in turnover in Fortune 1000 companies); Drake Beam Morin, $C E O$ Tumover and Job Security 8 (Special Report 2000) (finding "increased turnover and job loss at the highest corporate level" in an international study); Lorri Grube, CEOs at Risk, Chief Executive 42 (Nov 1, 1995) (reporting that executive turnover increased by more than a fourth between 1992 and 1995).

59 See Lyons, CEO Casualties: $A$ Battlefront Report, Directors \& Boards at 43 (cited in note 58) (listing "increasingly independent boards" as the first factor contributing to a "rash of leadership changes"); CEO Turnover Up, SF Bus Times (cited in note 58) ("CEO tenures are being cut short by impatient boards of directors and by unforgiving public markets"); Grube, Chief Executive at 42 (Nov 1, 1995) (cited in note 58) ("[I]ncreasingly powerful boards [ ] are impatient with subpar performance."). But see Morin, CEO Turnover and Job Security at 12 (cited in note 58) (conducting an international study finding that mergers and acquisitions are leading cause for CEO departure and that less than $10 \%$ of departures are due to dismissal or resignation); Huson, Parrino, and Starks, $56 \mathrm{~J}$ Fin at 2268, 2278 (cited in note 48) (finding statistical evidence that the percentage of outside directors increased between 1971 and 1994, the larger percentage of outside directors increases the likelihood of forced CEO turnover, and that, controlling for governance changes, likelihood of a forced CEO turnover was higher during 1989 to 1994 than in earlier periods).

60 See, for example, Mark J. Loewenstein, The Conundrum of Executive Compensation, 35 Wake Forest L Rev 1, 15-16 (2000) (noting the increasing independence of board members); Tod 
independence of outside directors, target CEOs can no longer assume that outside board members will support their decision to reject an unsolicited bid.

Second, and more visibly, the executive compensation structure has evolved to include an increasing reliance on stock options. Consider the following data: In 1980, less than one-third of U.S. CEOs held stock options. $^{61}$ By 1995, more than two-thirds of public companies compensated their CEOs with stock options. ${ }^{62}$ Among large companies, where direct equity stakes tend to be lower, stock options are even more prevalent. According to a 1996 study, a staggering $94 \%$ of the largest 250 companies use stock options as part of their compensation packages. ${ }^{63}$ In relation to the dollar value of overall $\mathrm{CEO}$ compensation, stock options, which accounted for a trifling $8 \%$ in $1985,{ }^{64}$ had by 1998 risen to 35\% of a CEO's compensation in public companies overall, and to $38 \%$ of the compensation of CEOs of Standard \& Poor's ("S\&P") 500 companies. ${ }^{65}$ Executives can reap substantial financial benefits from stock options when their company is acquired in a premium bid. These benefits are multiplied by golden parachutes, which provide for severance payments, benefits, early vesting of pension rights, and accelerated vesting of unvested options. ${ }^{66}$

Perry and Marc Zenner, CEO Compensation in the 1990s: Shareholder Alignment or Shareholder Expropriation?, 35 Wake Forest L Rev 123, 130 (2000) (concluding that directors may have become more vigilant monitors of CEOs); Melvin A. Eisenberg, Corporate Law and Social Norms, 99 Colum L Rev 1253, 1266 (1999) (noting increased level of directorial care over and rise of the monitoring boards during the 1990s); Ira M. Millstein and Paul W. MacAvoy, The Active Board of Directors and Performance of the Large Publicly Traded Corporation, 98 Colum L Rev 1283, 1284-86 (1998) (noting the increased independence of boards).

61 See Randall S. Thomas and Kenneth J. Martin, The Effect of Shareholder Proposals on Executive Compensation, 67 U Cin L Rev 1021, 1029 (1999) (observing that the percentage of CEOs holding stock options increased from $30 \%$ to almost $70 \%$ from 1980 to 1994). For a general discussion of the increased use of stock options in executive compensation, see Marcel Kahan, The Limited Significance of Norms for Corporate Governance, 149 U Pa L Rev 1869, 188890 (2000) (noting that $94 \%$ of the 250 largest U.S. companies use stock options as part of their compensation packages).

62 See Perry and Zenner, 35 Wake Forest L Rev at 129-30 (cited in note 60) (noting that, by 1995, the percentage of companies compensating their CEOs through stock options was up to $70 \%)$.

63 See Mark A. Clawson and Thomas C. Klein, Indexed Stock Options: A Proposal for Compensation Commensurate with Performance, 3 Stan J L, Bus, \& Fin 31, 42 (1997) (citing a 1996 study by Frederick W. Cook \& Co., Inc.).

64 See Linda J. Barris, The Overcompensation Problem: A Collective Approach to Controlling Executive Pay, 68 Ind L J 59, 64 (1992).

65 See Perry and Zenner, 35 Wake Forest $\mathrm{L}$ Rev at 131 (cited in note 60). See also David Yermack, Do Corporations Award CEO Stock Options Effectively?, 39 J Fin Econ 237, 238 (1995) (reporting an increase in the percentage of CEO compensation accounted for by stock options from $20 \%$ in 1984 to $30 \%$ in 1991 ).

66 See Ehud Kamar, Managerial Change-in-Control Benefits and Takeovers at 4, working paper (2001) (on file with authors) (examining the effect of stock options and early vesting on incentives to pursue a sale of the company). 
Equally noteworthy are the governance changes that did not occur. Market participants made relatively few efforts to constrain the use of poison pills and the power of the board to "just say no." According to conventional wisdom, managerial incentives to include efficient governance devices are strongest for companies that go public. ${ }^{67}$ But a study of charter provisions in over three hundred companies that went public between 1994 and 1997 found no single provision that prohibited or limited the use of poison pills or the board's authority to adopt antitakeover provisions in the future. ${ }^{6 s}$ To the contrary, a majority of firms included provisions that rendered takeovers more difficult than they would have been in a company with just a pill. Perhaps most tellingly, over $60 \%$ of the companies went out of their way to protect the board's ability to wield a poison pill by either establishing a staggered board or by making it difficult for shareholders to replace the board between annual meetings. ${ }^{69}$ A staggered board renders a hostile bidder's conventional response to a pill - the waging of a proxy contest concurrent with a tender offer, with a newly elected board redeeming the pill-more difficult since a bidder may have to wage proxy contests in two consecutive years to obtain a board majority. Similarly, under Delaware corporate law, when there is a staggered board the default setting for director removal between annual meetings shifts from "with or without cause" to "only for cause." If shareholders cannot replace the board between annual meetings, a raider has to wait until the annual meeting to conduct the proxy contests and consummate its bid.

With respect to companies that are already public, the evidence on opt-outs is somewhat more ambiguous. According to data compiled by Georgeson, a major proxy solicitation firm, shareholders, in the early years of the pill, sponsored a moderate number of precatory resolutions - an average of twenty-six per year during 1987 to 1991asking the board to redeem the pill or to submit it to a shareholder

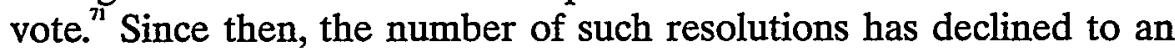
average of less than fifteen a year during 1996 to $2000 .^{n}$ The Investor

67 See, for example, Daines and Klausner, $17 \mathrm{~J} \mathrm{~L}$, Econ, \& Org at 85 (cited in note 45) (noting the common assumption that IPO-stage charter terms maximize firm value).

68 See id at 95.

69 E-mail from Michael Klausner to Marcel Kahan (Aug 29,2001) (reporting that $62.3 \%$ of the companies in the Daines-Klausner sample established a staggered board, prohibited removal of directors without cause, or did not give shareholders the right to call a special meeting or to act by written consent).

70 8Del Code Ann \$ 141(k) (1991).

71 See Georgeson Shareholder, Inc, 2000 Annual Meeting Season Wrap-Up: Corporate Governance 3 figure 2, available online at <http:/www.georgesonshareholder.com/pdf 00Wrapup.pdf (visited Mar 29, 2002).

72 See id. 
Responsibility Research Center ("IRRC") similarly reports a decline in the number of poison pill resolutions from twenty-one per year per one thousand firms during 1987 to 1991 to ten per year during 1996 to $2000 .^{3}$ On the other hand, both Georgeson and the IRRC find that the percentage of shareholder voting in favor of pill resolutions increased, from $27 \%$ (39\%) during 1987 to 1991 to $42 \%$ (57\%) during 1996 to $2000{ }^{74}$ Even resolutions that were approved by shareholders, however, generally did not result in the removal of a pill. ${ }^{75}$ Perhaps at odds with the IPO data, ${ }^{76}$ shareholders have voted in increasing number for reso-

73 See Michael Klausner, Institutional Shareholders' Split Personality on Corporate Governance: Active in Proxies, Passive in IPOs at 3, John M. Olin Program in Law and Economics Working Paper 225 (Nov 2001), available online at $<$ http://papers.ssrn.com/id=292083> (visited Mar 29, 2002). See also Stuart L. Gillian and Laura T. Starks, Corporate Governance Proposals and Shareholder Activism: The Role of Institutional Investors, 57 J Fin Econ 275, 286 (2000) (reporting that the number of poison pill resolutions declined between 1991 and 1994).

74 See Georgeson Shareholder, Inc, 1997 Annual Meeting Wrap-Up: Corporate Governance 7 fig 10, available online at <http://georgesonshareholder.com/pdf/97Wrapup.pdf (visited Mar 29, 2002); Georgeson Shareholder, Inc, 2001 Annual Meeting Wrap-Up: Corporate Governance 7 fig 10, available online at <http:/georgesonshareholder.com/pdf/01Wrapup.pdf $>$ (visited Mar 29, 2002). Some of the more recent proposals have been directed against dead-hand, rather than plain, poison pills. See TIAA-CREF Urges Nasdaq, NYSE to Require Shareholder Approval of Option Plans; Other 2001 Corporate Governance Initiatives Also Announced, PR Newswire (Feb 7,2001 ) (noting resolutions filed by TIAA-CREF to have dead-hand pill repealed). The Investor Responsibility Research Center, using a different method to track shareholder proposals, similarly finds that the number of poison pill proposals decreased from over fifty per year in 1990 and 1991 to an average of twenty-two per year in 1996 to 1998. See various issues of Investor Responsibility Rsrch Center Corp Gov Bull. During this period, shareholders have made only minimal efforts to get companies to adopt charter provisions-allowing shareholders to act by written consent or to call special shareholder meetings and making directors removable without cause-that would permit the replacement of directors between annual meetings and thus greatly reduce the effect of a pill. See various issues of Investor Responsibility Rsrch Ctr Corp Gov Bull (describing two proposals between 1990 and 1998).

75 See Council of Institutional Investors, 1998 Majority Vote Companies, available online at $<$ http://www.cii.org/majvote98.htm> (visited Jan 5, 2002) (reporting that, of four companies where pill proposal was approved by a majority of shareholders, none implemented the proposal); Council of Institutional Investors, 1999 Majority Vote Companies, available online at $<\mathrm{http} / / \mathrm{www} . \mathrm{cii} . \mathrm{org} /$ majvote99.htm> (visited Jan 5, 2002) (reporting that, of nineteen companies where pill proposal was approved by a majority of shareholders, seven implemented the proposal); Council of Institutional Investors, 2000 Majority Vote Companies, available online at $<$ http://www.cii.org/majvote00.htm> (visited Jan 5, 2002) (reporting that, of eighteen companies where pill proposal was approved by a majority of shareholders, two implemented the proposal); Council of Institutional Investors, 2001 Majority Vote Companies, available online at $<\mathrm{http} / /$ www.cii.org/majvote01.htm> (visited Jan 5, 2002) (reporting that, of nineteen companies where pill proposal was approved by a majority of shareholders, two implemented the proposal); Michael P. Smith, Shareholder Activism by Institutional Investors: Evidence from CalPERS, $51 \mathrm{~J}$ Fin 227, 234 (1996) (finding that of twenty-three anti-pill proposals made by CalPERS from 1987 to 1993 , one was adopted or resulted in a settlement). Note that the seven pill proposals from 1999 that were implemented included one mandatory bylaw amendment and at least two proposals concerning dead-hand pills. As discussed below, shareholders have been more successful in getting boards to repeal dead-hand pills, which are much more potent than regular pills in fending off takeovers. See also text accompanying note 112 .

76 The refusal of shareholders to vote for staggered boards can be reconciled with the inclusion of staggered boards in IPO charters. For example, staggered boards may be desirable for 
lutions calling on the board to propose declassification of existing staggered boards ${ }^{\pi}$ and, since the 1990 s, have largely succeeded in resisting charter amendments to establish staggered boards.

\section{OUR INTERPRETATION}

\section{A. The Domain of Strategic Responses}

Assume, arguendo, that many market participants disapprove of the takeover standards set by the Delaware courts. There are three

some companies (those that include such provisions in their IPO charters), but not for others (mature companies that do not have them already).

77 See Georgeson Shareholder, Inc, Annual Meeting Wrap-Up governance reports (various years) (cited in notes 71,74) (reporting that the average annual number of resolutions increased from less than one during 1987 to 1991 to twenty-three during 1996 to 2000 and percentage voting in favor increased from $27 \%$ in 1994 to an average of $44 \%$ between 1998 and 2000); Klausner, Institutional Shareholders' Split Personality at 3-4 (cited in note 73) (presenting IRRC data showing that average number of staggered board proposals per one thousand firms was twentyseven a year during 1987 to 1991 , with on average $22.5 \%$ of shareholders voting in favor; and thirteen a year during 1996 to 2000 , with on average $46.7 \%$ of shareholders voting in favor); Gillan and Starks, $57 \mathrm{~J}$ Fin Econ 275, 286 (cited in note 73) (reporting that the number of resolutions to repeal classified boards remained steady between 1989 and 1994, but the number of such resolutions sponsored by institutional investors or coordinated shareholder groups increased substantially). The relatively greater willingness of shareholders to accept antitakeover provisions in IPOs than in midstream amendments was accompanied by (and maybe caused) a shift in academic opinion about the relative efficiency of the IPO and the amendment process. In the 1980s, the leading proponents of the "let shareholders decide" approach to takeovers also regarded the governance provisions adopted in IPOs as more reflective of what maximized shareholder value than the provisions that shareholders approved in "midstream" charter amendments. See, for example, Lucian Arye Bebchuk, Limiting Contractual Freedom in Corporate Law: The Desirable Constraints on Charter Amendments, 102 Harv L Rev 1820, 1822-25 (1989) (favoring stricter limits on midstream changes in charter terms but basically favoring contractual freedom in IPO terms); Jeffrey N. Gordon, The Mandatory Structure of Corporate Law, 89 Colum L Rev 1549, 1553-55, 1557-62 (1989) (same); Ronald J. Gilson, Evaluating. Dual Class Common Stock: The Relevance of Substitutes, 73 Va L Rev 807, 808-10 (1987). But see Roberta Romano, Answering the Wrong Question: The Tenuous Case for Mandatory Corporate Laws, 89 Colum L Rev 1599, 1607-11 (1989) (criticizing argument that shareholders blindly vote according to management recommendations). Since then, the faith in shareholder voting decisions seems to have increased remarkably and the terms included in IPO charters are regarded as less convincing evidence of what maximizes shareholder wealth. Nowadays, the same academics who argued against midstream shareholder votes in the 1980s want to rely on shareholder votes to remove takeover barriers, despite the fact that no takeover enhancing provisions are included in IPO charters. See Gilson, 26 Del J Corp L at 507-09 (cited in note 1) (favoring shareholder ability to adopt bylaws removing pills); Bebchuk, $69 \mathrm{U}$ Chi L Rev at 980, 988, 1028 (cited in note 1) (advocating judicial invalidation of pill once shareholders have replaced a minority of a staggered board).

78 See Lucian Arye Bebchuk and Allen Ferrell, A New Approach to Takeover Law and Regulatory Competition, $87 \mathrm{Va}$ L Rev 111, 126-28 (2001) (noting that "those companies that did not already have classified boards at the start of the 1990s have found it practically impossible to get the necessary shareholder approval of any charter amendment adopting a classified board"); Klausner, Institutional Shareholders' Split Personality at 3-4 (cited in note 73) (presenting IRRC data showing that number of board proposals to amend the charter to establish a staggered board per one thousand firms has declined by about $90 \%$ from 1986 to 2000 , and attributing decline to management's realization that shareholders are unlikely to vote in favor of such proposals). 
strategies that market participants can pursue. First, they can seek to change the law. Legal change can be pursued in a number of different ways. For one, market participants can pursue legislative action. They could lobby the Delaware legislature to pass a law changing the takeover standards set by courts. ${ }^{79}$ Similarly, they could lobby Congress or, in some cases, the Securities and Exchange Commission to preempt Delaware law with federal laws or regulations. Alternatively, market participants could try to modify the law through the common-law process, by having Delaware courts overturn, limit, or modify their prior decisions. We will refer to this first set of strategies as the pursuit of legal change.

Second, market participants could induce individual companies to reincorporate or change their governance structure through charter or bylaw amendments. These amendments can either directly "opt out", of objectionable provisions of Delaware law or they can otherwise indirectly change the effect of such law. For companies that are already public, reincorporations and charter amendments require the approval of both shareholders and directors, ${ }^{81}$ while bylaw amendments typically require the consent of either the board or shareholders. For companies that go public, the board typically determines the content of the IPO charter and bylaws taking into account the effect, if any, of these provisions on the IPO share price. We will refer to this strategy as the pursuit of opt-outs.

Third, market participants could seek to modify the corporate governance and managerial incentive structure by other means. The various elements of the governance and incentive structure interact with each other, often in complex ways. A change in the legal standard or an exogenous shock (such as an increase in the risk of hostile takeovers) can upset the balance between a legal standard and the other elements of the incentive structure. One way to reestablish the bal-

79 In every state where the courts prohibited the use of poison pills, the state legislature overturned the decision. See Eric S. Robinson, John C. Coates IV, and Mitchell S. Presser, State Takeover Statutes: A Fifty State Survey (1989) (privately published, on file with authors).

80 The term "opt out" is slightly inaccurate, as sometimes the action is better thought of as opting in to some particular governance arrangement (for example, a staggered board).

81 In most instances, companies would have to amend their charter or reincorporate into a different state to opt out of a legal rule. See, for example, Gilson, 34 Stan L Rev at 780-92 (cited in note 7) (examining antitakeover provisions adopted as charter amendments). Charter amendments and reincorporations must be approved by both the board and shareholders. See 8 Del Code Ann § 242(b) (1991 \& Supp 1999) (charter amendments) and § 251(b)-(c) (1991 \& Supp 1997) (mergers). In some instances, a company can opt out of a legal rule through a bylaw provision, which typically requires approval by either the board or shareholders. Companies could also try to opt out de facto by spinning off substantial assets through subsidiaries that are incorporated in a different jurisdiction or contain different charter provisions. But see Hilton Hotels Corp v ITT Corp, 878 F Supp 1342, 1351 (D Nev 1997) (enjoining spin-off of substantial assets in midst of takeover battle). 
ance is to modify the other elements to create a new equilibrium. Adaptive devices that rebalance the governance and incentive structure can take multiple forms, including changes in the compensation regime, changes in board composition, changes in the shareholder composition, or changes in the capital structure. Depending on the device, adoption may require formal approval by the board and/or shareholders, approval by outside directors, actions by corporate officers, or actions by a subgroup of shareholders. We will refer to this strategy as the pursuit of adaptive devices.

In drawing a distinction between legal change, opting out and adaptive devices, we are trying to draw attention to different modes of response. Legal change requires action by the legislature, a regulatory agency, or the courts. Opting out requires private action, but in a formal state-created regulatory framework. By contrast, adaptive devices can take a variety of forms, many of which are more graduated and less formal than legal change and opt-outs.

All three of these strategies have been pursued from time to time. For example, judicial rulings holding poison pills invalid were quickly overturned by state legislatures. ${ }^{82}$ Similarly, the SEC's enactment of Rule $13 \mathrm{e}-4^{\mathrm{s}}$ to prohibit discriminatory self-tender offers overturned the Delaware Supreme Court ruling in Unocal Corp v Mesa Petroleum $\mathrm{Co}^{8 /}$ that permitted such an offer. ${ }^{85}$ And the negative reactions of prominent M\&A lawyers to rulings by the Chancery Court that questioned the validity of the "just say no" defense were clearly aimed to get Delaware to revise those decisions.

A clear example of opting out is the widespread adoption of charter amendments that limit directors' monetary liability for nonintentional breaches of the duty of care. These amendments were prompted by the Delaware Supreme Court's ruling in Smith $v$ Van Gorkom, ${ }^{\text {s }}$ which was seen to enhance the risk of such liability, and the subsequent passage of section 102(b)(7) of the Delaware General Corporation Law, ${ }^{\mathrm{N}}$, which permitted opt-out amendments. Another recent instance of systematic opting out in response to a change in the

82 See note 79.

83 Amendments to Tender Offer Rules-All-Holders and Best-Price, SEC Securities Act Release No 6653, [1986-87 Transfer Binder] Fed Sec L Rptr (CCH) I 84,016 (July 11, 1986); Tender Offers by Issuers, SEC Securities Act Release No 6596, [1984-85 Transfer Binder] Fed Sec L Rptr (CCH) $\mathbb{1} 83,798$ (July 1,1985) (proposing an amendment to the rules).

84493 A2d 946 (Del 1985).

85 See id at 958-59 (finding that Unocal's offer was reasonable in relation to the threat).

86 See Gordon, 91 Colum L Rev at 1959, 1959 n 95 (cited in note 20) (quoting from two Wachtell, Lipton, Rosen \& Katz memoranda urging that "Delaware act[] quickly to correct" the ruling and warning that unless "it is ... reversed by the Delaware Supreme Court," companies may migrate out of Delaware).

87488 A2d 858 (Del 1985).

888 Del Code Ann \$ 102(b)(7) (1991 \& Supp 1993). 
law involved Pennsylvania's strict antitakeover statute enacted in 1990. In the immediate aftermath of the enactment, most exchangetraded Pennsylvania companies opted out of one or more prongs of the statute. Since the enactment, companies reincorporating into Pennsylvania regularly opt out of its antitakeover laws. ${ }^{\text {." }}$ Other examples of opting out include the variety of antitakeover charter amendments enacted in the early years of the tender offer boom and the massive reincorporation of companies from New Jersey in the 1910s.

The takeover setting also provides examples of the adoption of adaptive devices that change the practical significance and effect of a corporate law provision by modifying other parts of the incentive structure. Indeed, as discussed below, such devices-specifically, changes in board composition and in the executive compensation regime-changed the significance of the takeover standards set by the Delaware courts. Other examples of adaptive devices in the takeover setting include the establishment of employee stock ownership plans ("ESOPs") in the 1980s, which placed voting power in the hands of the company's employees, who were expected to oppose takeovers out of concern over job cuts," and substantial increases in debt, which may have enhanced efficiency by reducing the agency cost of free cash flows."

\section{B. The Tradeoff Among Strategic Responses}

How does one choose among strategies for responding to change or, for that matter, decide whether to respond at all? While a detailed examination of this question goes beyond the scope of this Article, we begin, at least, to sketch the boundaries of the domain of choice. Broadly speaking, from the perspective of a group of dissatisfied market participants, strategies differ along two dimensions: their effectiveness in rectifying a problem and the ease with which they can be implemented. For legislative reversal, dissatisfied market participants

89 See Roberta Romano, Competition for Corporate Charters and the Lesson of Takeover Statutes, 61 Fordham L Rev 843, 859 (1993) (finding that forty-three of sixty-three exchange traded firms opted out of all or portions of Pennsylvania's takeover statute, that fifteen did not, and that no information was available as to the remaining five firms).

90 See Marcel Kahan and Ehud Kamar, The Myth of State Competition, working paper (2002) (on file with authors) (finding that all three companies that reincorporated into Pennsylvania between 1998 and 2000 opted out of all of the provisions of its antitakeover law). See also Daines and Klausner, $17 \mathrm{~J} \mathrm{~L}$, Econ, \& Org at 97 (cited in note 45) (finding that all Pennsylvania firms in a study of 310 IPOs opted out of Pennsylvania's disgorgement statute).

91 See generally Eric Grannis, Note, A Problem of Mixed Motives: Applying Unocal to Defensive ESOPs, 92 Colum L Rev 851 (1992) (analyzing the ESOP defense).

92 See Michael C. Jensen, Agency Costs of Free Cash Flows, 76 Am Econ Rev Papers and Proceedings 323, 324-25 (1986) (arguing that increases in debt can reduce managerial agency costs). 
must possess the political power to get a new law enacted. This may be the case when there is a broad consensus among market participants that the present law is just plain wrong. Most amendments to the corporate code in Delaware are the product of such a consensus. ${ }^{93}$ Legislative reversal may also occur when one interest group or a coalition of groups captures the political process. Many commentators interpret the antitakeover statutes passed by several states, albeit not necessarily the one passed by Delaware, as resulting from the capture of the legislative process by a few large local employers, possibly in coalition with employee representatives."

Legal change through judicial action differs from legislative reversal in several respects. First, judges do not directly respond to political pressure the way legislatures do and often act for nonpolitical reasons. Second, legal change through judicial action is often a byproduct of an individual controversy between two parties, rather than the result of a broad strategy to accomplish legal change. Third, judgemade law is typically more open-ended, more flexible, and less determinate than statutory law. Depending on the issues involved, legal change through judicial actions may therefore be more or less easily implemented, and be more or less effective, than legal change through legislative action. Delaware fiduciary duty case law, which contains numerous instances in which a court has refined or retracted portions of earlier opinions," can be interpreted as a reflection of one or more of these differences.

93 See Curtis Alva, Delaware and the Market for Corporate Charters: History and Agency, 15 Del J Corp L 885, 903-16 (1990) (discussing the political process that produces amendments to Delaware's corporate law).

94 See Kahan and Kamar, The Myth of State Competition (cited in note 90); Romano, 61 Fordham L Rev at 854-56 (cited in note 89) (noting that in most states "[t]akeover laws are typically sponsored by a local chamber of commerce at the behest of a major domestic corporation," while, because of the large number of firms incorporated in Delaware, "no one firm's management has the clout to get a bill enacted"); Henry N. Butler, Corporation-Specific Anti-Takeover Statutes and the Market for Corporate Charters, 1988 Wis L Rev 365, 373 (arguing that the passage of many antitakeover laws reflects the influence of particular corporations in the state legislature). But see Lucian Bebchuk and Alma Cohen, Firms' Decisions Where to Incorporate at 27, Harvard Olin Discussion Paper No 351 (Feb 2002), available online at $<$ http://www.law.harvard.edu/programs/olin_center/> (visited Apr 9, 2002) (suggesting that standard antitakeover statutes are intended to attract incorporations); Guhan Subramanian, The Influence of Antitakeover Statutes on Incorporation Choice: Evidence on the "Race" Debate and Antitakeover Overreaching at 40-43, Harvard NOM Research Paper No 10-10 (Dec 2001), available online at <http://papers.ssrn.com/abstract=292679> (visited Apr 9, 2002).

95 Examples of cases that refine the legal standard include: Unocal, 493 A2d 946, 954-55 (Del 1985) (establishing intermediate standard of review); Moran v Household International, Inc, 490 A2d 1059, 1076 (Del Ch 1985) (subjecting poison pills to Unocal review); Revlon, 506 A2d at 184 (establishing stricter standard for sale or breakup of a company); and Brazen $v$ Bell Atlantic Corp, 695 A2d 43, 47-49 (Del 1997) (reviewing termination fee under rules of liquidated damages, rather than the business judgment rule). $Q V C$, Weinberger, and Rabkin are all examples of retractions. Paramount Communications, Inc v QVC Network, Inc, 637 A2d 34, 37-45 (Del 1993) 
Opt-outs, in turn, have two potential advantages over legal change. First, opt-outs may be easier to implement than legislative change. Opt-outs require either the governance power to obtain board and/or shareholder approval for an opt-out by an existing public company or the "pricing power" to induce managers to opt out when they take a company public. Thus, as a result of either shareholder pressure or directorial judgment, many existing Pennsylvania companies opted out of the state's antitakeover regime, ${ }^{\text {, }}$ which was enacted to protect a politically powerful local employer. ${ }^{97}$ Second, opt-outs may be more effective if firms are heterogeneous and the desired rule varies from company to company.

Adaptive devices also may be pursued either because they are easier to implement or because they are more effective. Adaptive devices may be easier to implement because the requisite action necessary for adoption does not require formal legislative, board, or shareholder approval. Adoption may be easier for other reasons as well. The device may be less visible and therefore generate less opposition (compare, for example, informal pressure to redeem a poison pill with a formal bylaw amendment requiring redemption)." Similarly, its effect may be more ambiguous or less well understood (an ESOP, for example, could serve as an antitakeover device or as a bona fide benefits plan). Further, it may have a greater claim to legitimacy (it is hard to oppose more independent directors). Finally, an adaptive device may be easier to implement because it utilizes carrots rather than sticks (contrast, for example, incentives from executive compensation and incentives from the threat of legal liability). Setting aside ease of implementation, an adaptive device can enable parties to achieve their goals more effectively than legislative change or opting out because it offers more flexibility and fine-tuning (compare, for example, a more independent board with a prohibition of poison pills). More generally,

(retracting portions of Time-Warner on whether change of control triggers Revlon); Rabkin $v$ Philip A. Hunt Chemical Corp, 498 A2d 1099, 1104-06 (Del 1985) (retreating from the exclusivity of appraisal approach in Weinberger, 457 A2d 701); Weinberger v UOP, Inc, 457 A2d 701, 715 (Del 1983) (retreating from the business purpose test of Singer v Magnavox Co, 380 A2d 969 (Del 1977).

96 See Roberta Romano, The Genius of American Corporate Law 68-70 (AEI 1993) (finding that out of 199 Pennsylvania firms with identifiable choices, "127 opted out of all or part of the [antitakeover] statute, while 72 firms did not").

97 See Leslie Wayne, Many Companies in Pennsylvania Reject State's Takeover Protection, NY Times A1 (July 20,1990) (noting that "[t]he law was introduced into the Pennsylvania legislature at the urging of Armstrong World Industries to fend off an unwanted takeover bid").

98 For example, directors may prefer to implement voluntarily a suggestion made by shareholders, rather than have the shareholders make a formal proposal submitted to shareholders at large, in order to avoid the humiliation of an adverse shareholder vote.

99 For example, both greater use of stock options and greater restrictions on takeover defenses make it more likely that an unsolicited bid will be consummated, but managers are likely to favor the former over the latter. 
because adaptive devices come in many forms, with different approval requirements and different economic effects, they greatly increase the flexibility of market participants.

To some degree, legal change, opting out, and adaptive devices represent different ways of achieving similar goals. The attractiveness of each strategy therefore relates, both statically and over time, to the attractiveness of the alternative strategies. Thus, for example, to the extent that adaptive devices are easily available and effective, the pressure on legislative or judicial alternatives will be reduced. Moreover, if an innovation improving the attractiveness of one strategy emerges, the prevailing balance between the strategies can change. The innovation of the poison pill, for example, reduced the pressure for legal change or the adoption of antitakeover charter provisions. ${ }^{100}$ By the same token, dissatisfaction with the existing governance and incentive structures and difficulty in modifying them can increase incentives to develop innovations in each of the strategies. For example, the attempt to introduce mandatory bylaw amendments to redeem poison pills can be understood as an innovative opt-out strategy necessitated by the failure of boards to respond to informal shareholder pressure and precatory resolutions.

\section{Responses to Takeover Law}

How, then, do the last twenty years of mergers and acquisitions relate to this framework? To start with, in the 1980s, there was an exogenous shock to the corporate law system. What, exactly, triggered the takeover boom of the 1980 s is unclear and multifactored, ${ }^{101}$ but, in the space of a few years, the world changed. Hostile takeovers became commonplace and provided new challenges to the existing legal structure. ${ }^{102}$ This exogenous shock triggered a variety of changes, including changes in Delaware's takeover jurisprudence.

In retrospect, how did the corporate world respond-and not respond-to the 1980s Delaware takeover decisions? First, Delaware did not change its statutory law significantly, ${ }^{103}$ for example, by passing

100 In contrast, in states where courts held poison pills invalid, the pressure for legislative change increased, and led, in all such cases, to the enactment of legislation permitting poison pills. See note 79 .

101 See Bengt Holmstrom and Steven N. Kaplan, Corporate Governance and Merger Activity in the United States: Making Sense of the 1980s and 1990s, $15 \mathrm{~J}$ Econ Perspectives 121, 123-32 (Spring 2001) (examining the structural triggers of the takeover boom).

102 See Gilson, 26 Del J Corp L at 493-97 (cited in note 1) (discussing Delaware's response to the changing corporate climate).

103 See William T. Allen, Jack B. Jacobs, and Leo E. Strine, Jr., The Great Takeover Debate: A Meditation on Bridging the Conceptual Divide, $69 \mathrm{U}$ Chi L Rev 1067, 1068 (2002) ("[A]mendments to the DGCL have rarely been the method used to confront the major developments occurring in the mergers and acquisitions marketplace."). 
a law prohibiting poison pills and other frustrating actions absent shareholder approval (the kind of approach taken by the U.K. in the City Code). ${ }^{104}$ Delaware's principal legislative effort ${ }^{105}$-the adoption of its moderate antitakeover law, codified as Section 203 of the Delaware General Corporation Law in 1988-was largely moot by the time it was enacted. ${ }^{106}$ Unlike post-Van Gorkom, there was no sufficiently broad political consensus that Delaware takeover law was wrong or, if wrong, about how it should be changed. The contentious battle over the takeover sections of the American Legal Institute's Principles of Corporate Governance provides some anecdotal evidence of the absence of consensus, ${ }^{107}$ as does the long-running debate in the law reviews described earlier.

One did, of course, find the Delaware Supreme Court and Chancery Court playing active roles in the development of Delaware takeover law. But the tensions and disagreements between the Chancery Court's approach and the Supreme Court's approach, ${ }^{108}$ and the doctrinal tensions within each approach, provide further evidence of the difficulty of forging standards that are clear, consistent, and acceptable to most market participants.

Second, and strikingly - at least for corporate law academics critical of Delaware's approach-market participants did not induce many companies to opt out of Delaware law through charter provisions. ${ }^{109}$ Such charter provisions could have, in line with the views held

104 On the U.K. approach, see Paul L. Davies, Gower's Principles of Modern Company Law 783 (6th ed 1997):

[A]fter a bona fide offer has been committed to the board of the target ... no action may be taken by the board without the approval of the company in general meeting which could result in the offer being frustrated or to shareholders being denied an opportunity to decide on its merits.

105 There have been some other, relatively narrow, legislative changes in Delaware, such as the recent amendment to Section 251 of the Delaware Code that permits directors to submit a merger to a shareholder vote that they were ready to recommend when the merger agreement was signed but are no longer ready to recommend at the time of the vote. See R. Franklin Baloti and Jesse A. Finkelstein, The Delaware Law of Corporations \& Business OrganizationsStatutory Deskbook $\$ 251$ at 219 (Aspen 1999) (amending Section 251 of the Delaware General Coporation Law). There have also been some legislative and regulatory changes in federal law. See, for example, note 83 .

106 See John C. Coates IV, Takeover Defenses in the Shadow of the Pill: A Critique of the Scientific Evidence, 79 Texas L Rev 271, 320-23 (2000) (showing how the pill dominates most other takeover defenses and arguing that, with judicial approval and widespread adoption of the pill in the late 1980 s, these other defenses became vestigial).

107 See A.A. Sommer, Jr., Review of Charles Hansen, A Guide to the American Law Institute Corporate Governance Project, 51 Bus Law 1331, 1332-33 (1996) (describing some of the "many firestorms generated by the ALI initiative").

108 See, for example, Time-Warner, 571 A2d at 1153 (criticizing Interco and not adopting Chancery Court's reasoning in the case at bar).

109 Frank Easterbrook and Dan Fischel, two leading academic opponents of the Delaware takeover jurisprudence, took it for granted that companies would opt out of it when they went 
by many academic commentators, either restricted poison pills directly or made them ineffective by ensuring that shareholders could replace directors outside of the annual meeting. With already-public companies, one might argue that such opting out did not happen because Delaware law requires board approval (in addition to shareholder approval) to amend the charter. ${ }^{\text {.10 }}$ Managers opposed to such amendments may thus have been able to prevent their passage. In other instances, however-most notably in response to Pennsylvania's antitakeover law - the board's power to block charter amendments did not prevent massive opt-outs of takeover-inhibiting laws." Similarly, shareholders are enjoying significant success in their efforts to get boards to repeal dead-hand features of poison pills. ${ }^{12}$ The fact that in some circumstances boards have agreed to remove takeover-inhibiting provisions, but that boards have not agreed to redeem regular pills, suggests that the requirement of board approval does not, by itself, explain when takeover defenses are repealed.

Moreover, the requirement of board approval does not explain why takeover-enhancing provisions were not included in the charters of companies that go public, when pre-IPO owners have incentives to adopt governance provisions that maximize the price at which they can sell shares to the public. One does not, for example, find IPO charters that limit the use of poison pills or incorporate the City Code's "no frustrating actions" standard. ${ }^{113}$ To the contrary, to the extent that IPO charters and bylaws contain special provisions, they inhibit hostile takeovers. ${ }^{114}$ To be sure, the failure to adopt takeover-enhancing provisions in IPO charters does not conclusively establish that such provisions would not increase firm value. Maybe imperfections in IPO pricing dull the incentives to adopt value-maximizing governance provisions. ${ }^{115}$ Maybe entrepreneurs do not rationally pursue their long-run self-interest in setting governance terms during IPOs, or maybe the

public. See Easterbrook and Fischel, Economic Structure of Corporate Law at 205 (cited in note 17) (asserting (inaccurately) that "lirms go public in easy-to-acquire form: no poison pill securities, no supermajority rules or staggered boards. Defensive provisions are added later.").

110 See 8 Del Gen Code Ann $\$ 242$ (b) (1991 \& Supp 1999).

111 See text accompanying notes $89-90$.

112 See TIAA-CREF Urges Nasdaq, NYSE to Require Shareholder Approval of Option Plans, PR Newswire (cited in note 74) (noting that fifty-one of sixty corporations approached by TIAA-CREF agreed to remove dead-hand features from their pills).

113 See Davies, Gower's Modern Company Law at 783 (cited in note 104) (citing General Principle 7).

114 See Daines and Klausner, $17 \mathrm{~J} \mathrm{~L}$, Econ, \& Org at 85 (cited in note 45) (examining the charters and bylaws of 310 firms going public and finding that two-thirds had provisions to impede hostile acquisitions and that no firms had terms to avoid subsequent adoption of antitakeover provisions).

115 See id at 113 (noting the possibility that antitakeover provisions in IPO charters are not fully priced). 
governance provisions that maximize the value of start-ups differ from those that maximize the value of mature companies. Nevertheless, the general failure to opt out to make Delaware law more takeoverenhancing - whether by charter amendments or in an IPO-warrants the conclusion that market participants regard the board's ability to "just say no," unlike, for example, Pennsylvania's law or dual-class stock, ${ }^{116}$ as not seriously detracting from company value, and possibly as enhancing it.

Rather than by changing the law or opting out of it, market participants principally adjusted to Delaware takeover law through adaptive devices. ${ }^{17}$ As discussed earlier, one finds significant changes in the structure of compensation contracts during this period, with new means of incentive alignment being developed, and older mechanisms being used more widely and intensively. ${ }^{118}$ Specifically, we find much higher magnitudes of stock options granted to executives, with features such as accelerated vesting upon a change of control. ${ }^{119}$ Such compensation devices provide substantial incentives to managers to accept an unsolicited takeover bid. ${ }^{120}$ Consistent with our interpretation of stock options as adaptive devices to management's power to resist a bid, managers in companies with antitakeover provisions re-

116 See id at 95-97 (finding that all Pennsylvania firms in their sample opted out of Pennsylvania's disgorgement statute and that only $6.4 \%$ of all firms in the sample had dual-class stock).

117 For purposes of our argument, it does not matter whether market participants pushed for a more independent board and incentive compensation because of the effect of these measures on incentives to accept a takeover bid. While such a causal connection is plausible, it is sufficient for our argument that market participants noted that these measures, adopted for whatever reason, had the effect on such incentives and took this effect into account in deciding how to respond to Delaware's takeover regime.

118 See text accompanying notes $61-66$.

119 To be sure, another reason for the increase in stock options was a change in the tax laws that limited the deductibility of compensation in excess of $\$ 1$ million unless such compensation was performance related. This change provided an incentive for companies to substitute stock options and performance based bonuses for fixed salary. Of these two devices, however, stock options provide greater incentives to agree to an acquisition than bonuses. In fact, during the 1990 s, stock options increased by much more than bonuses. While stock options may also have other advantages over bonuses (such as a lesser impact on current earnings or lesser manipulability), the facts are consistent with our conjecture that stock options acted as an adaptive device to takeovers.

120 See Kamar, Managerial Change-in-Control Benefits and Takeovers at 12-17 (cited in note 66) (analyzing benefits managers can derive in a change of control). Others have noted the interrelation between the poison pill's entrenchment effects and the structure of executive compensation. See also Jeffrey N. Gordon, Poison Pills and the European Case, 54 U Miami L Rev $839,840-41$ (2000) (describing the shift in entrenchment effects of the pill as stock options become more prevalent in executive compensation). 
ceive more valuable options, ${ }^{121}$ and managers of companies with large blockholders receive fewer options. ${ }^{12}$

In addition, independent directors play an increasing role in the governance of public corporations. ${ }^{123}$ The presence of independent directors makes it more likely that a board will be receptive to an unsolicited offer. For one, the independent directors may not go along with a decision to reject the offer. Second, because of the independent directors, a CEO's tenure may already be less secure. ${ }^{124}$ This has several effects. It means that the CEO has less to gain by fighting to stay on. It also means that, given the standard compensation contracts, there is all the more reason to depart with the rich send-off of a sale, rather than the less generous provisions of a normal termination. Finally, departing in the context of a sale of control is likely to be better for a CEO's reputation than being fired by the board.

There is substantial evidence that these devices have neutralized to a substantial extent managerial opposition to unsolicited bids. Most importantly, the high level of $M \& A$ activity indicates that there are no high barriers to deals. Also, poison pills are mostly used by target boards to buy time (and bargaining power) in order to negotiate a higher price with the raider or to find a white knight, rather than to "just say no."125

Our framework suggests that there are two plausible explanations for the failure to pursue seriously a strategy seeking opt-outs or legislative change in response to the takeover standard developed by Delaware. First, the ultimate complex takeover regime-combining power of the board to block a bid (and to threaten to block a bid to extract a higher price), financial incentives for target managers to accept one, and oversight by outside directors with increased substantive independence-may indeed reflect an equilibrium that is superior to the one that could be achieved by opt-outs or by legal change establishing a "let shareholders decide" regime. Shareholders, in other words, may have learned to love the pill. According to this explanation, shareholder pressure to remove pills would be isolated and concentrated in the relatively few companies that failed to adopt effective

121 See Kenneth A. Borokhovich, Kelly R. Brunarski, and Robert Parrino, CEO Contracting and Antitakeover Amendments, 52 J Fin 1495, 1503-12 (1997) (finding higher levels of CEO compensation at companies which had adopted antitakeover amendments).

122 Harley E. Ryan, Jr. and Roy A. Wiggins III, The Influence of Firm- and Manager-Specific Characteristics on the Structure of Executive Compensation, 7 J Corp Fin 101, 104 (2001) (finding a "negative relation between stock options and blockholder ownership").

123 See text accompanying notes 46-59.

124 See text accompanying notes 58-59.

125 See Lipton, $69 \mathrm{U}$ Chi L Rev at 1053 (cited in note 1) (noting that, since Time-Warner, not a single Delaware court decision has addressed an instance in which directors used a pill to "just say no"). 
adaptive devices. Such pressure would be intended as much to induce boards to adopt such devices as actually to remove pills. Supporting this explanation, anti-pill proposals are relatively rare, have declined over time, and are associated with a decline in the stock price. ${ }^{126}$ Even institutions that have taken a leading role in corporate governance matters and categorically oppose other antitakeover devices, such as dual-class shares, dead-hand pills, or reincorporations into states with significant antitakeover legislation, take a case-by-case approach to regular pills." We will refer to this explanation as the "effectiveness hypothesis."

Alternatively, shareholders may have lacked both the political power to change the law and the governance power to achieve optouts. The reduction in the efforts to induce opt-outs reflects a realization of the futility of that strategy, not an embrace of the pill. What shareholders could do, however, they did do: They largely prevented the passage of new takeover-inhibiting charter amendments and, when a proposal to redeem a pill was on the ballot, they voted for it by increasing margins. ${ }^{128}$ Beyond that, shareholders had to compromise with managers, offering them huge piles of money to buy off their opposition to unsolicited bids and subjecting them merely to the less threatening discipline of independent directors rather than to the less forgiving takeover market. At least given the availability of these devices, pursuit of this compromise was seen as a superior strategy to a more antagonistic (and less likely to be successful) pursuit of opt-outs. Shareholders, then, do not love the pill, but they have learned to live with the pill. As to IPOs, other explanations-such as the notorious abnormalities in IPO pricing or the strong attachment entrepreneurs may feel to companies they take public-account for the absence of takeover-enhancing, and the presence of takeover-inhibiting, charter terms. We will refer to this explanation as the "implementability hypothesis."

126 See text accompanying notes 73-74; John M. Bizjak and Christopher J. Marquette, Are Shareholder Proposals All Bark and No Bite? Evidence from Shareholder Resolutions to Rescind Poison Pills, 33 J Fin \& Quant Analysis 499, 519 (1998) (finding empirical evidence that anti-pill resolutions are associated with a decline in the share price); Georgeson Shareholder, Inc, Corporate Governance: Institutional Voting on Poison Pill Rescission 3, available online at <http://www.georgesonshareholder.com/pdf/CGpoisonpill.pdf> (visited Mar 30, 2002) ("[S]hareholder proposal proponents tend to target companies with poor performance."). This explanation is also consistent with the fact that the declining number of anti-pill proposals that are made garner increased support by shareholders. See text accompanying note 74 .

127 See TIAA-CREF Policy Statement on Corporate Governance, available online at $<$ http://www.tiaa-cref.org/libra/governance/index.html> (visited Mar 30, 2002) ("In evaluating proposals with anti-takeover implications, TIAA-CREF will consider the broad context of takeover defenses at a particular company.").

128 See text accompanying notes 73-74. 
What is most striking about the recent history of takeovers is that, regardless of which hypothesis is correct, the use of adaptive devices seems to work reasonably well for the participants. The level of M\&A activity, the percentage of friendly versus hostile deals, the decline in efforts to adopt "show stopping" charter amendments such as dual-class recapitalizations, and the failure of states offering extreme antitakeover measures such as dead-hand pills to attract incorporations all suggest that the intensity of managerial insecurity has been tempered, and with it managers' opposition to selling the company. For buyers, the current state seems satisfactory: Payments owed managers under incentive compensation contracts can be budgeted into the price; the amounts, while large for CEOs, are of the same order of magnitude as investment banking fees and amount to a relatively small percentage of the deal price; and market participants generally assert that deals that make economic sense get done.

For target shareholders, the current state likewise seems satisfactory: Managers have largely adopted "shareholder value maximization" as their mantra; target shareholders earn significant premia in friendly deals; and the market through the 1990s soared. Finally, the current state suits most potential target managers: They stand to get rich on their options and their "golden parachute" packages should they be made redundant by an acquisition.

Overall, political controversy over takeovers has died down and the more hyperbolic claims by the partisans - that permitting a board to block a bid amounts to "corporate treason" board from blocking a bid constitutes "a dagger aimed at the hearts" of corporations-have vanished from the public debate. In other words, the system as a whole is in an equilibrium with no substantial pressure for radical change. The only people who think that there remains a systematic problem to be solved are commentators who view the threat of managers being penalized by a hostile tender offer as an essential tool for disciplining management or who resent the high levels of compensation engendered by stock options. ${ }^{131}$

\section{IMPLICATIONS AND ANALYSIS}

Our interpretation of the events of the last twenty years has a number of implications, which we explore in this Part. They relate to the predictability of the effects of exogenous shocks once market par-

129 Gilson, 35 Stan L Rev at 52 (cited in note 16).

130 Gordon, 91 Colum L Rev at 1959 n 95 (cited in note 20) (quoting Wachtell, Lipton, Rosen \& Katz memorandum).

131 See, for example, Bebchuk and Ferrell, 87 Va L Rev at 113 (cited in note 78) (advocating federal intervention to generate a "let shareholders decide" regime). 
ticipants had the chance to respond to these shocks, to the distinction between unilateral and bilateral responses and the privileged position of bilateral responses in Delaware law, to our assessment of how and why Delaware sanctioned the poison pill, and to the danger of staleness in corporate governance structures in general, and the argument that staggered boards reflect such staleness in particular.

\section{A. The Possibility of Responses Makes It Harder to Predict the Effects of a Legal Development}

Our analysis of how the takeover battles of the 1980s evolved into the wave of friendly deals in the 1990s has several lessons. The most basic is that the effect of exogenous shocks and doctrinal developments-such as the rise in hostile takeovers and the developments in Delaware takeover law-cannot be analyzed ceteris paribus, assuming that nothing else changes. Rather, such developments must be analyzed mutatis mutandis, taking into account the changes made in response.

In the area of corporate law, such an analysis is often difficult. First, there is a multiplicity of ways of responding-pursuing legal change, pursuing opt-outs, pursuing various types of adaptive devices-each with its own power dynamics. Second, the collective action and information problems affecting shareholders mean that shareholder-initiated responses may be uneven among issues, among companies, and over time. Third, differences-both among firms and over time-in the composition of boards, the shareholder profile, and so on, will cause different firms to respond to legal developments in ways that are different and that are not always conducive to the maximization of firm value.

Responses to doctrinal developments have indeed ameliorated, neutralized, or even reversed their initial effect. Consider, for instance, Van Gorkom, which at the time was viewed as greatly increasing the potential liability of directors for breaches of their duty of care. In response to Van Gorkom, Delaware passed a statute permitting companies to adopt charter provisions opting out of such liability, ${ }^{132}$ and most companies availed themselves of that option. Thus, Van Gorkom may have been a major case ceteris paribus, but turned out largely insignificant mutatis mutandis. Similarly, "just say no" was a much more problematic defense in the corporate governance world of the 1980s than it is today, with differently constituted boards and different incentive compensation regimes. Finally, consider what happened in those states in which courts invalidated poison pills-decisions pre- 
sumably applauded by protakeover commentators. In each of these states, legislation permitting pills was enacted. ${ }^{133}$ In one instance, that legislation turned out not merely to sanction regular pills, but to validate the dead-hand pill, which Delaware courts have struck down as per se invalid. ${ }^{134}$

\section{B. Unilateral versus Bilateral Responses}

We have argued above that the responsive behavior of the 1980s and 1990s largely moved in the right direction and resulted, overall, in increased firm value. In a sense, this is evidence of the welfare effects of flexibility. The 1980s takeover decisions generated a situation in which large potential gains could be obtained by improving incentives: If managers could be led to act in shareholders' interests, firm value would increase substantially. The silver lining of the agency cost cloud in big U.S. firms is that the amounts that you need to pay managers to do the right thing are generally small compared to the benefits that doing the right thing creates for shareholders. We view the spread of adaptive devices as a mix of carrots (generous stock options) and mild sticks (more independent boards) that created such incentives. From this vantage point, the last twenty years represent a fascinating case study of how corporate governance structures adapted to a new environment.

This, however, does not mean that each and every move along the way was itself welfare-enhancing. In particular, we want to distinguish between responses that were partially bilateral-that is, that enjoyed some measure of support, formal or informal, by both shareholder groups and management-and those that were unilateral - that is, that were pursued by one of these groups against strong opposition by the other. The distinction between bilateral and unilateral devices is important in two respects. First, the more bilateral a device is, the more likely it is to be welfare-enhancing and stable. Second, attention to the degree of bilateral-ness helps shed light on Delaware's regulation of takeovers.

1. The distinction between unilateral and bilateral responses.

To illustrate the distinction between unilateral and bilateral strategic responses, consider the increased number and independence of

133 See Robinson, Coates, and Presser, State Takeover Statutes (cited in note 79).

134 See Invacare Corp v Healthdyne Technologies, Inc, 968 F Supp 1578 (N D Ga 1997) (interpreting Ga Code Ann $\$ 14-2-624$, which was passed to override a court decision that invalidated regular poison pills, to sanction dead-hand pills). But see Bank of New York Co, Inc v Irving Bank Corp, 528 NYS2d 482, 485 (1988) (invalidating a dead-hand pill not included in the target's certificate of incorporation). 
outside directors, on the one hand, and dead-hand poison pills, on the other. The changes in board composition over the last twenty years are due to formal and informal shareholder pressure and to boards acting of their own accord. In the former case, shareholders did not encounter strong managerial opposition. Boards became increasingly independent with the acquiescence of incumbent board members; confrontational election contests designed to increase the number of independent directors are practically unheard of. In the latter case, shareholders were cheering while their board was acting. By now, outside board members have largely taken control over the nominating process and majority-outside boards have thus become, to some extent, self-perpetuating. ${ }^{135}$ By contrast, dead-hand poison pills were validated, legislatively or judicially, over shareholder opposition and are adopted by boards over shareholder opposition. In our terminology, the increasing independence of boards is a bilateral governance device; the dead-hand pill is a unilateral device.

\section{Welfare effects and stability of strategic responses.}

We hypothesize that bilateral devices are more likely to be welfare-enhancing than unilateral devices. More specifically, bilateral devices are usually welfare-enhancing; unilateral devices, by contrast, may or may not be welfare-enhancing. Our rationale for this hypothesis is twofold. First, it relates to the direct effect of the device. Second, it relates to the stability of the device.

Relative to unilateral devices, bilateral devices bring shareholders and managers to the bargaining table. As the product of a consensual and reflective participatory process, the direct effect of the device is likely to be a Pareto improvement. At the same time, however, bilateral devices are likely to reflect compromises when the interest of managers and shareholders conflict. Because of these two features, bilateral devices will tend to reflect an acceptable solution for shareholders and managers, but not necessarily the optimal solution for either; they will tend to constrain self-interested managerial actions that are highly detrimental to shareholders, but also entail payoffs to managers that may be greater than deserved. ${ }^{136}$ Their overall direction, however, generally will be to enhance welfare.

Moreover, because a bilateral device is based on compromise and consensus, it is not likely to engender a strategic response that eradi-

135 Korn/Ferry International, 27th Annual Board of Directors Study at 13 (cited in note 48) (noting that, by $2000,74 \%$ of boards had nominating committees and that these committees were, on average, composed of three outside board members and no inside board members).

136 See Borokhovich, Brunarski, and Parrino, 52 J Fin at 1503-12 (cited in note 121) (finding that managers of companies with antitakeover provisions receive both higher salaries and more valuable stock options than managers of companies without such provisions). 
cates or reverses its direct effect. As a result, if the direct ceteris paribus effect of a bilateral device is to enhance welfare, it is likely that the overall mutatis mutandis effect will also be welfare-enhancing. By contrast, unilateral devices are more likely to generate a strong strategic response, thus making their mutatis mutandis effect harder to predict.

Critics may respond that the dichotomy between unilateral and bilateral devices is a false one. Rather, the real distinction lies between devices that shareholders can approve on their own accord-which are presumptively wealth enhancing - and devices that boards can approve on their own accord-which are suspect (with devices that require both shareholder and board falling in between).

Maybe so. We agree that, as owners, it is shareholders who have the ultimate sovereignty over corporate decisionmaking. Indeed, corporate law accords shareholders such sovereignty, with the caveat that shareholders must usually exercise it indirectly via board members elected by the shareholders. We think that excluding boards from corporate decisionmaking engenders several problems. ${ }^{137}$ Shareholderelected boards have information and expertise beyond that available to shareholders at large. Boards also have the capacity to protect shareholders against actions designed to exploit shareholders' collective-action problems-such as coercive offers ${ }^{133}$ or even noncoercive "take it or leave it" offers - and board members can more easily be held accountable for breaches of their fiduciary duties. Finally, as long as boards retain (as they must in public corporations) the power to manage the company, a unilateral, board-opposed governance measure is likely to induce a strategic response by the board.

\section{Bilateral Devices and Delaware Corporation Law}

Whether bilateral devices are more likely to be welfareenhancing than unilateral devices, they hold a privileged position in Delaware corporate law. This bias in favor of compromise in Delaware takeover law is a product of strong pressures to compromise deep in the structure of Delaware corporate law more generally. With a structure favoring compromise, it is not surprising that, when the challenge of hostile takeovers emerged in the 1980 s, the Delaware response sought to channel conduct in familiar directions.

137 See Bebchuk, 69 U Chi L Rev at 1028 (cited in note 1) (agreeing that boards should be permitted to delay shareholder votes for some period due to such problems).

138 See Bebchuk, 98 Harv L Rev at 1717-33 (cited in note 7) (describing the distorted choice that shareholders face in takeover bids). 
1. The importance of bilateral devices.

Consider the important decisions that require bilateral approval. The Section 251 merger, which is in some ways the paradigm Delaware mechanism for the transfer of control, requires a board resolution and approval by shareholders. ${ }^{139}$ A sale of all or substantially all the assets requires approval of both the board and the shareholders. ${ }^{\text {tho }}$ Any amendment to the charter requires board recommendation and shareholder approval. ${ }^{141}$ Finally, dissolution requires a board recommendation and shareholder approval, unless shareholders unanimously approve it. ${ }^{142}$

The substantial deference that Delaware gives to decisions that are approved by informed shareholders reinforces this tendency. For example, in conflict transactions, shareholder approval removes the "void or voidable" taint and can both shift the burden of proof and change the ultimate standard of review. ${ }^{143}$

Delaware's approach to outside directors has a similar effect. Outside directors stand, in many ways, between managers and shareholders and are thus potential agents of compromise. On the one hand, they are usually less informed than managers, but better informed than shareholders, and, in crisis situations, can obtain additional information and act more easily than shareholders can. On the other hand, they have less potential bias than managers do (since they earn comparatively little for their board service), but also often do not have substantial equity stakes in the company. Moreover, Delaware in contrast to other jurisdictions, ${ }^{144}$ employs both formal and substantive scrutiny before it gives weight to actions by outside directors. For an outside director to be deemed "independent," the absence of an executive position or of a financial interest in the transaction is not sufficient. Rather, to be regarded as an independent director, an outside director must act independently and take her role as such seriously. ${ }^{14}$

139 See 8 Del Code Ann $\S 251$ (b)-(c) (1991 \& Supp 1997).

140 Id \& 271 (1991 \& Supp 1997).

141 See id $\$ 242$ (b) (1991 \& Supp 1999).

142 See id $\$ 275$ (1991).

143 See Lewis $v$ Vogelstein, 699 A2d 327, 338 (Del Ch 1997) (finding that recent cases accorded "substantial effect to shareholder ratification").

144 See, for example, Michigan Business Corporation Act, Mich Comp Laws Ann $\S 450.1107(3)$ (West 1990) (defining "independent director" largely by reference to formal criteria).

145 See, for example, Rabkin v Philip A. Hunt Chemical Corp, 498 A2d 1099, 1106 (Del 1985) (criticizing an independent committee for not negotiating and holding that approval by committee did not change standard of analysis); Kahn $v$ Tremont Corp, 694 A2d 422, 429-30 (Del 1997) (criticizing members of an independent committee for not devoting sufficient care to their tasks and holding that approval by the committee did not change the standard of anaiysis); Mills Acquisition Co v Macmillan, Inc, 559 A2d 1261, 1265 (Del 1988) (finding that in the "absence of any serious oversight by the allegedly independent directors," a board's action has to meet the 
Approval by substantively independent directors in itself adds a measure of bilateralism to the device. Indeed, we find that Delaware encourages the approval of substantively independent directors in a host of contexts. Approval by independent directors is critical, for example, in the setting of executive compensation. Similarly, and more generally, approval by independent directors shifts the burden of proof in transactions between an interested controlling shareholder and the firm, and can shift both the burden of proof and the applicable standard of review in transactions between an interested director and the firm.

Further, corporate law affords a much greater scope for changing the governance structure of a corporation through charter amendments, which require the approval of both the board and of shareholders, than through bylaw amendments, which can be passed unilaterally by either the board or the shareholders. Under Delaware law, there is great flexibility in what can be included in the charter:

[One may include] [a]ny provision for the management of the business and for the conduct of the affairs of the corporation, and any provision creating, defining, limiting and regulating the powers of the corporation, the directors, and the stockholders, or any class of the stockholders ... if such provisions are not contrary to the laws of this State. ${ }^{145}$

Turning now specifically to takeover law, one finds the same deference to the product of bilateral decisionmaking. For example, Delaware courts invalidated a dead-hand poison pill adopted unilaterally by the board, holding that such a pill would be valid only if incorporated in a charter provision approved by shareholders. ${ }^{1.7}$ In the same vein, the court held that charter amendments approved by shareholders do not need to pass enhanced scrutiny under Unocal. ${ }^{148}$ We similarly predict that Delaware courts will hold that shareholders cannot unilaterally adopt bylaw provisions restricting poison pills. Contrary to conventional wisdom, ${ }^{149}$ we would regard such a holding as enhancing shareholder rights. Both the board and shareholders have the unilateral power to adopt bylaw amendments, and the de facto ability to

\footnotetext{
standard of "intrinsic fairness").

1468 Del Code Ann \& 102(b)(1) (1991).

147 Quickturn Design Systems, Inc v Shapiro, 721 A2d 1281, 1291-92 (Del 1998) (holding that Delaware law requires any limitation on a board's authority be set out in the certificate of incorporation).

148 Williams v Geier, 671 A2d 1368, 1377 (Del 1996) (determining that a "Unocal analysis should be used only when a board unilaterally ... adopts defensive measures").

149 See, for example, Gilson, 26 Del J Corp L at 507 (cited in note 1) ("Fifteen years of experience with Unocal teaches that shareholders ought to decide whether to accept an offer made to them.").
} 
pass such amendments is much higher for the board than for shareholders. ${ }^{150}$ Thus, it is in the long-run interest of shareholders to limit the domain that can be regulated by bylaws when the interests of shareholders and managers conflict.

The greater deference to decisions by disinterested directors also carries over to the takeover context. When independent directors form a majority, "proof that the board acted in good faith and upon reasonable investigation is materially enhanced." tiny of board actions under Revlon and its progeny can also be understood as limitations on unilateral governance decisions. Enhanced Revlon scrutiny applies to takeover defenses in transactions when the company or control over the company is being sold. Such defenses are inherently more unilateral than "just saying no" since, after the transaction is consummated, shareholders lack the power to oust the board. In other words, Revlon prevents a board from using the cover of a pill to take unilateral actions that render the shareholders' ability to remove the board and repeal the pill meaningless. This renders the decision closer to the bilateral decision of a classic merger under Section 251.

Finally, when a board adopts unilateral measures that overstep the proper bounds, Delaware courts do not just limit the measures to their proper size. Rather, they invalidate them as a whole. Thus, for example, the Delaware Supreme Court invalidated the lock-up options and termination fees granted by the target boards in Revlon and Paramount Communications, Inc v QVC Network, Inc ${ }^{152}$ rather than reducing their amount or removing the features that the court deemed objectionable. ${ }^{153}$ This all-or-nothing approach reduces the relative attraction of unilateral measures by increasing the downside risk.

2. Bilateral devices and Delaware's position in the market for incorporations.

Interestingly, an approach that induces consensus and compromise is consistent with Delaware's interests as the leading producer in the market for incorporations. For several decades, Delaware has

150 A board can act quickly and faces no collective action problem. In addition, in some companies there is a supermajority requirement for shareholder bylaw amendments.

151 Ivanhoe Partners v Newmont Mining Corp, 535 A2d 1334, 1343 (Del 1987), citing, inter alia, Polk v Good, 507 A2d 531, 537 (Del 1986); Revlon, 506 A2d at 176 n 3; and Moran v Household International, Inc, 500 A2d 1346, 1356 (Del 1985).

152637 A2d 34 (Del 1993).

153 See id at 37 (invalidating the lock-up option and suggesting to the Chancery Court that the termination fee should also be invalidated). See generally David A. Skeel, Jr., $A$ Reliance Damages Approach to Corporate Lockups, $90 \mathrm{Nw}$ U L Rev 564 (1996) (proposing a different approach of distinguishing which lock-up provisions should be enforced based on the bidder's reliance interest). 
faced no major competitor in its efforts to attract incorporations by public companies. ${ }^{15}$ Franchise taxes from these companies are an important source of revenue for Delaware, accounting for more than $24 \%$ of its total tax revenues. ${ }^{155}$ Thus, the major risk for Delaware is not a gradual erosion of its competitive advantages, but a seismic shift that would leave important constituents-shareholders, managers, or financial intermediaries-highly dissatisfied. Such a shift could fracture the market for incorporations - with some companies opting for a state with pro-shareholder laws and others for a state with promanagement laws-or generate the political support necessary for the adoption of a federal corporate law. In either case, Delaware would stand to lose significant revenues. This is the enduring lesson of New Jersey's failure in the 1910s and Delaware's subsequent rise to prominence as the domicile of choice. ${ }^{156}$

The advent of hostile takeovers could have produced such a seismic shift. Takeovers brought to the fore issues where the amounts of money at stake were large and the conflicts between shareholders and managers significant. The challenge for Delaware was to come up with a set of rules that, in conjunction with adaptive devices, would leave both shareholders and managers sufficiently satisfied to avoid significant governance pressure on existing public companies to reincorporate elsewhere, to avoid significant market pressure to induce companies to incorporate elsewhere at the IPO stage, and to avoid significant political pressure to pass a federal corporate law. Put this way, Delaware's challenge was to "satisfice" rather than optimize."

Delaware's cautious approach-the contextual, two-stepsforward-one-step-back tendency of its case law, the fact that its takeover statute came late and was mild, and its encouragement of bilateral responses-can all be understood as responses to this challenge. Recall, from our earlier discussion, that to the extent that parties can

154 See Marcel Kahan and Ehud Kamar, Price Discrimination in the Market for Corporate Law, 86 Cornell L Rev 1205, 1210-14 (2001) (pointing to Delaware's profitability as evidence of its market power).

155 See Government's Recommended Operating and Capital Budget Information: Financial Overview, available online at <http://www.state.de.us/budget/fy2003/op_fin_ov.pdf $>$ (visited Mar 31,2002 ) (projecting $\$ 593$ million franchise tax revenues in $\$ 2.3$ billion budget for fiscal year 2003).

156 See William L. Cary, Federalism and Corporate Law: Reflections upon Delaware, 83 Yale L J 663, 663-65 (1974) (pointing out that changes in New Jersey's corporate law led to Delaware's rise).

157 This term was coined by economist Herbert Simon to describe a decisionmaker who is willing to "settle for good-enough answers in despair of finding the best answers." See, for example, Herbert A. Simon, Administrative Decisionmaking, 25 Pub Admin Rev 31, 33 (1985). See also Herbert A. Simon and Joseph B. Kadene, Optimal Problem-Solving Search: All-or-None Solutions, in Herbert A. Simon, 1 Models of Bounded Rationality: Economic Analysis and Public Policy 248 (MIT 1982). 
reach equilibrium through adaptive devices, the pressure to pursue legal change or to opt out will be reduced. ${ }^{158}$ In the takeover context, this meant that the ability to achieve a satisfactory equilibrium within the Delaware system removed pressure either to change the law through federal intervention or to opt into a different state's takeover law through reincorporation, either of which could have undermined Delaware's preeminence.

From today's perspective, Delaware passed this test with flying colors. Federal law did not significantly encroach on the takeover area; as shown in Table 4, the proportion of public companies incorporated in Delaware is rising; Delaware's franchise tax receipts have reached unprecedented levels; ${ }^{159}$ and states that adopted a radically promanagement takeover regime did not attract substantial incorporations."

158 See Part II.B.

159 See Kahan and Kamar, 86 Cornell L Rev at 1211 (cited in note 154) (documenting the increase in franchise tax revenues).

160 See text accompanying note 90. See also Subramanian, The Influence of Antitakeover Statutes on Incorporation Choice at 54-61 (cited in note 94) (finding that these laws reduced incorporation); Daines and Klausner, $17 \mathrm{~J} \mathrm{~L}$, Econ, \& Org at 96-97 (cited in note 45). 


\section{TABLE 4}

\section{PERCENTAGE OF COMPANIES INCORPORATED IN DELAWARE BY IPO YEAR}

\begin{tabular}{|c|c|}
\hline IPO Year & $\begin{array}{c}\text { \% incorporated in } \\
\text { Delaware }\end{array}$ \\
\hline 1980 & $39 \%$ \\
\hline 1981 & $45 \%$ \\
\hline 1982 & $31 \%$ \\
\hline 1983 & $40 \%$ \\
\hline 1984 & $39 \%$ \\
\hline 1985 & $48 \%$ \\
\hline 1986 & $60 \%$ \\
\hline 1987 & $72 \%$ \\
\hline 1988 & $59 \%$ \\
\hline 1989 & $61 \%$ \\
\hline 1990 & $62 \%$ \\
\hline 1991 & $64 \%$ \\
\hline 1992 & $69 \%$ \\
\hline 1993 & $61 \%$ \\
\hline 1994 & $60 \%$ \\
\hline 1995 & $67 \%$ \\
\hline 1996 & $70 \%$ \\
\hline 1997 & $62 \%$ \\
\hline 1998 & $66 \%$ \\
\hline 1999 & $76 \%$ \\
\hline 2000 & $81 \%$ \\
\hline
\end{tabular}

Source: Robert Daines, The Market for Corporate Law: Lawyers, Takeovers, and the Home Court Advantage at Appendix A, working paper (on file with authors).

D. The Poison Pill Reassessed

So what do we make of the poison pill at the end of the day? At least in the first instance, poison pills are adopted unilaterally by the board of directors. Indeed, the fact that the pill did not require shareholder approval was one of its main attractions. As a doctrinal matter, Delaware courts could easily have held that a poison pill requires shareholder approval, for example, by analogizing the pill to a stock transfer restriction rather than, as it did, to an antidilution provision in convertible securities. ${ }^{161}$ Yet they did not. How then does the pill fit

161 See Moran v Household International, Inc, 500 A2d 1346, 1352 (Del 1985) (endorsing analogy of a poison pill to an antidilution provision). A pill resembles a transfer restriction in 
into our discussion of the welfare effects and the stability of unilateral devices and to our assessment of Delaware's preference for bilateralism?

For one, though adopted unilaterally by directors, a regular poison pill - the only kind valid in Delaware-has several bilateral features. First, as the court stressed in Moran v Household International, $I n c^{162}$ and reaffirmed in Quickturn Design Systems, Inc v Shapiro, ${ }^{163}$ shareholders must retain the ultimate authority to remove a pill by replacing the board. Second, it is independent directors, rather than the board as a whole, who call the shots on whether to redeem the pill when faced with a hostile bid. And third, because the pill has not been approved by shareholders, any specific decision by the board on whether to redeem the pill is scrutinized by the court under Unocal. And this scrutiny, while lax when the pill is used to "just say no," remains meaningful when the pill is used to cram-down on shareholders a defensive maneuver designed to inhibit a takeover bid. ${ }^{164}$ Thus, the ultimate effect of the pill is akin to "just say wait": it leaves the decision on whether to accept a bid to the outside board members, but only until shareholders can replace the board, and in the meantime discourages defensive board actions.

Despite these bilateral features, Moran can be viewed as a decision that was discontinuous with the deep structures of Delaware law-an experiment, if you will. But note how this experiment was conducted. The pill was endowed with bilateral features that ameliorated its unilateral effect. These features were even more pronounced in early pills, which permitted shareholders to redeem a pill. And though Moran permitted the use of certain flip-over pills, it was not until much later-when the court could see how market participants reacted to and employed pills - that it became clear that boards could adopt much stronger flip-in pills, without shareholder redemption features, to "just say no." By proceeding incrementally, the courts could monitor the course of the experiment, with the ability to limit the effect of the pill if it proved necessary. The Interco doctrine, for example, was one approach the Delaware Supreme Court could have taken if the pill had proved too potent..$^{165}$ This cautious approach also allowed

that its effect is to encumber the transfer of shares to a shareholder when that transfer would trigger the pill. It is no coincidence that Delaware's antitakeover law, which has a similar effect as the pill, is included in the subchapter on stock trarisfers.

162500 A2d 1346 (Del 1985).

163721 A2d 1281 (Del 1998).

164 See Time-Warner, $571 \mathrm{~A} 2 \mathrm{~d}$ at 1154-55.

165 A second, less convincing, justification for the pill is that it restored the bilateralism of a Section 251 merger. This justification is problematic for several reasons that have been discussed in the literature, including: that Delaware does not prevent managers from evading the bilateralism of a Section 251 merger by using a triangular merger structure; that a tender offer itself is 
for the evolution of adaptive devices. It may also have prevented worse results. Recall that in every state where courts blocked poison pills, the legislatures overruled the courts, leading in one state to the permissibility of dead-hand pills. ${ }^{160}$ And even if the pill had been universally invalidated, management could have (as it did prior to the pill) resorted to other, more destructive defenses.

In the end, the pill was part of an array of responses to the exogenous shock generated by the increase in takeovers. Permitting boards to adopt pills unilaterally was a departure from Delaware's commitment to bilateral devices, but a measured one and one taken at a time when bilateral regulation of takeovers was not a realistic option. Ultimately, the pill contributed to a new equilibrium in which it seems to have been transformed into a device that plausibly is in shareholders' interests and certainly one with which shareholders can easily live.

\section{E. Staggered Boards and the Danger of Staleness}

Both for academics and shareholder rights advocates, the action has moved from the pill to staggered boards. While the number of anti-pill proposals has steadily declined, shareholder resolutions calling for the elimination of staggered boards are on the rise. Hardly any public corporation without a staggered board, aware of strong shareholder opposition, dares to propose inclusion of such a term in the corporate charter. ${ }^{168}$ Corporate governance theorists and empiricists regard a staggered board combined with a pill to be a much more potent takeover defense than a pill by itself and have adduced empirical evidence that staggered board provisions reduce shareholder wealth. ${ }^{169}$ Indeed, the theoretical ability of shareholders to replace a board that refused to redeem a pill against shareholder wishes is substantially reduced in companies with staggered boards.

Unlike pills, of course, a staggered board provision in the charter is a fundamentally bilateral device: shareholders either voted for the

simply a sale of shares unregulated by the statute and, under Delaware's independent legal significance doctrine, should be presumed to be intentionally unregulated; and that the argument is ultimately circular in that it presumes that the statutory structure intends that all changes of control be bilaterally approved. See Gilson, 33 Stan L Rev at 845-47 (cited in note 7).

166 See note 134.

167 Delaware courts could have, of course, outlawed all defenses, but this would hardly have encouraged bilateralism.

168 See text accompanying notes 77-78.

169 Lucian Arye Bebchuk, John C. Coates IV, and Guhan Subramanian, The Anti-Takeover Power of Classified Boards: Theory, Evidence and Policy, 55 Stan L Rev (forthcoming 2002); Robert Daines, Does Delaware Law Improve Firm Value?, 62 J Fin Econ 525, 546 (2001); Robert M. Daines, Do Classified Boards Affect Firm Value?: Takeover Defenses after the Poison Pill at 16-18, working paper (2001) (on file with authors). 
provision or bought stock of a company with such a provision at an IPO. ${ }^{170}$ The controversy over staggered boards, however, points to another potential shortcoming of a system based on bilateral devices. The price of a consensus-based system is that it privileges the status quo. This, of course, is not a problem if the status quo reflects a compromise that remains acceptable to shareholders and managers. But what if the status quo loses its bilateral acceptability, either because market participants have changed their views or because the legal or economic context has changed? Then, a requirement of bilateral approval for change really amounts to giving the side that benefits from the status quo the unilateral power to veto a more appropriate resolution. This is a problem of "staleness" or legal obsolescence."

The problem of staleness is a real problem. In a common law system with a statutory base, the system evolves and can find that features interact in unanticipated ways. Thus, for example, in 1969, Section 228 of the Delaware General Corporate Law was amended to permit shareholders to act by written consent outside of the annual meeting unless restricted by the certificate of incorporation. ${ }^{17}$ The amendment was meant as a pure convenience and as such was uncontroversial. Yet, with the arrival of hostile takeovers, written consent provisions took on a very different meaning and provided an unanticipated route for removing incumbent directors. These provisions enable shareholders to replace a board between annual meetings in companies where directors can be removed without cause. Thus, such provisions have the unanticipated effect of substantially reducing the board's ability to use a pill to block or delay a hostile bid. Though some boards may strongly dislike this effect,'it takes shareholder approval to opt out.

Staggered boards, as several commentators have suggested, may also represent a status quo that no longer commands bilateral approval, ${ }^{1 / 3}$ but this time with the shoe on the other foot. Many staggered

170 The notable exceptions are Massachusetts and Maryland companies, where antitakeover laws imposed a staggered board (Massachusetts) or granted boards the unilateral power to adopt a staggered board (Maryland). See Daines, Do Classified Boards Affect Firm Value at 10-13 (cited in note 169) (discussing Massachusetts law); Md Corp and Assoc Code § 3-803 (1999 \& Supp 2001) (giving boards the power to establish staggered board without shareholder approval).

171 See generally Guido Calabresi, A Common Law for the Age of Statutes (Harvard 1982).

172 See Del Code Law Ann $\S 228$ (1969) (noting amendment by Ch 148, Laws of 1969).

173 See Sharon Hannes, Future Oriented Defaults: Reexamining the Limits of Contractual Freedom in Corporate Law at 21-23, Harvard Law School Graduate Program Working Paper, available online at <http:/www.law.harvard.edu/Admissions/Graduate_Programs/publications/ papers/hannes.pdf $>$ (visited Apr 19, 2002) (suggesting that staggered boards can lead to corporate stagnation); Bebchuk, Coates, and Subramanian, 55 Stan L Rev (forthcoming) (cited in note 169); Daines, Do Classified Boards Affect Firm Value at 3, 5-7 (cited in note 169); Bebchuk and Ferrell, 87 Va L Rev at 126-28 (cited in note 78) (noting that since the start of the 1990s corpora- 
board provisions were adopted in charters prior to the advent of the poison pill. Prior to the pill, a staggered board did not prevent a hostile bidder from consummating a tender offer and acquiring a majority of shares. Faced with inevitable (though not immediate) ouster, the argument continues, incumbents would cave in and resign. Thus, prior to the pill, staggered boards did not block hostile takeovers. However, now that companies have pills, a staggered board is a strong antitakeover device. To overcome a pill, a hostile raider must replace the board in a proxy contest. In a company with a staggered board, this takes over a year-longer than most raiders are willing to wait. If shareholders had foreseen this, the argument concludes, they would not have approved a staggered board to start with. In this world, requiring both shareholder and board approval to remove staggered boards does not induce compromise, but arbitrarily entrenches management.

Though this reasoning is plausible, it is not unassailable. For one, even prior to the advent of the pill, staggered boards served as a device to make it harder for shareholders to replace boards if they were dissatisfied and were often adopted as an antitakeover device. ${ }^{17 / 4}$ After all, what other plausible purpose could such provisions have served? ? $^{175}$ Moreover, while staggered boards did not prevent the consummation of tender offers per se, they may well have deterred bids. A hostile bidder, faced with an intransigent board that cannot be replaced for up to two years, may decide not to spend billions to acquire stock of a company that it does not control. Even a bidder willing to proceed would have had difficulty in financing a bid with debt, as bids in the 1980s were typically financed, if the raider couldn't assure the lender that he would control the target if the bid succeeds. ${ }^{176}$ Thus, a staggered

tions have found it practically impossible to get shareholder approval to amend charters to include staggered boards and that shareholders have voted in large numbers to repeal existing staggered boards); Klausner, Institutional Shareholders' Split Personality at 2-3 (cited in note 73) (noting the increasing votes for proposals to declassify boards since 1987).

174 Indeed, at the time when shareholders passed charter amendments providing for staggered boards, they also passed other antitakeover amendments. Staggered boards were clearly recognized to be an antitakeover measure. See Disclosure in Proxy and Information Statements; Anti-takeover or Similar Proposals, SEC Securities Act Release No 15230, [1978 Transfer Binder] Fed Sec L Rptr (CCH) I 81,748 (Oct 13, 1978). Many academic commentators at that time attributed such votes to invidious managerial pressure or plain shareholder inability to figure out what is good for them.

175 The usual argument for staggered boards, to assure some general continuity in board membership, rings hollow in the context of director elections, where absent a takeover or proxy contest, incumbent directors are very likely to be renominated and reelected to their seats. See Allen, Jacobs, and Strine, $69 \mathrm{U}$ Chi L Rev at 1073 (cited in note 103). Continuity is only an issue when shareholders make a concerted effort to oust incumbent management (that is, during a control contest) - and in this context staggered board provisions obviously serve as a device to make it harder for shareholders to replace the board.

176 The usual structure of a debt financed bid in the 1980s required the bidder to make the assets of the target available as security for the debt incurred to finance the bid. To do this, a hos- 
board may have been a more potent antitakeover device prior to the advent of the pill than today's academic critics of staggered boards let on. This, as well as the fact that $40 \%$ of the companies that went public post-pill have charters providing for staggered board, takes some wind out of the sails of those commentators who argue that the poison pill fundamentally changed the antitakeover effect of staggered boards and who would want courts to read such provisions out of existence. ${ }^{17}$

Interestingly, there have been remarkably few cases where incumbents held on after losing the first round of a proxy contest. Maybe directors give more heed to shareholder votes than the argument against staggered boards credits them. Moreover, no Delaware court has ever elaborated what showing a staggered board must make to maintain a pill after shareholders have elected a slate favoring redemption of the pill. ${ }^{178}$ This suggests that there is, with respect to the possible staleness of staggered boards, a solution that is consistent with Delaware's penchant for bilateralism. In applying enhanced scrutiny under Unocal to a decision by a divided board to "just say no," Delaware courts could explicitly take into account that shareholders have elected a slate that supports a takeover bid. Specifically, the fact that one-third of the board favors acceptance of the bid could be a factor in assessing the importance of the corporate objective threatened; the fact that shareholders would have to wait for a full year until the next board election could be a factor in assessing whether a refusal to redeem the pill - which prevents a sale of shares between consenting adults - is reasonable in relation to the threat. ${ }^{179}$ We do not believe, however, that Unocal analysis requires the court to strike down a pill whenever directors with a classified board suffer an election defeat. ${ }^{180} \mathrm{~A}$ more moderate approach, such as the one sketched above, would render the ability of shareholders to override a board decision-a power that according to Moran is a reason why unilateral pills are valid to start with-more meaningful; it would encourage a more deliberative process by independent directors if they want to retain the pill; it would respect the difference in governance arrangements

tile bidder would have to control the board of the target and freeze-out any nontendering shareholders.

17 See Bebchuk, 69 U Chi L Rev at 1034-35 (cited in note 1); Hannes, Future Oriented Defaults at 21-26 (cited in note 173); Bebchuk, Coates, and Subramanian, 54 Stan L Rev (forthcoming) (cited in note 169).

178 See Allen, Jacobs, and Strine, 69 U Chi L Rev at 1080 (cited in note 103) (describing this question as "open"). But see Bebchuk, Coates, and Subramanian, 55 Stan L Rev (forthcoming) (cited in note 169) (arguing that, coupled with a staggered board, the strength of the pill discourages raiders from initiating a vote).

179 See Time-Warner, $571 \mathrm{~A} 2 \mathrm{~d}$ at 1152 (holding that Unocal analysis requires inquiry into importance of corporate objection and reasonableness of defensive measure).

180 See Bebchuk, 69 U Chi L Rev at 1028 (cited in note 1) (proposing such a rule); Bebchuk, Coates, and Subramanian, 54 Stan L Rev (forthcoming) (cited in note 169) (same). 
between companies that have a staggered board and those without; ${ }^{181}$ and it would be unlikely to provoke a managerial counterstrike.

\section{CONCLUSION}

The takeover wave of the 1980s destabilized the governance structure of U.S. corporations and generated significant public controversy over the legitimacy of defensive devices. Twenty years later, the corporate governance structure has reached a new equilibrium and the public controversy has largely died down.

In this Article, we examined the events of the last twenty years from two perspectives. First, we considered how market participants reacted to the challenges presented by hostile takeovers in general and the judicial validation of the poison pill in particular. Here, we suggest that market participants largely responded by adopting informal adaptive devices rather than by pursuing legislative change or by formal optouts. Specifically, corporate boards became more independent and the executive compensation regime changed to provide managers with substantial benefits in the event of a change of control. Through these devices, the pill-a potentially pernicious governance measure that has been foisted upon shareholders without their permission and often against their will-was transformed into a device that is plausibly in shareholders' interests. Moreover, these devices-which were largely adopted with the approval, or at least the acquiescence, of both managers and shareholders-restabilized the governance structure and subdued the controversy over takeover defenses.

Second, we considered how Delaware law responded to, and shaped, these events. Here, we suggest that the distinction between bilateral devices (which enjoy support from both shareholders and managers) and unilateral devices (which are adopted by one group in face of opposition by the other) is important for an understanding of Delaware takeover law. Delaware corporate law generally privileges bilateral devices, which are likely to be welfare-enhancing, enjoy greater stability, and tend to further Delaware's status as the leading domicile for public corporations. The initial validation of the poison pill was a partial, and experimental, exception from Delaware's general preference for bilateral devices. Over time, however, Delaware succeeded in fashioning a more consensual approach to the regulation of takeovers. While this episode illustrates the potential benefits from bilateralism, the preference for bilateral devices also tends to enshrine the status quo and may lead to undesirable staleness in the governance structure of corporations.

181 See Allen, Jacobs, and Strine, $69 \mathrm{U}$ Chi L Rev at 1090 (cited in note 103) (noting that the staggered board reflects that shareholders may not change strategy in a single election). 


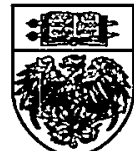

